This article was published in Renewable and Sustainable Energy Reviews, 41, 1489-1500, 2015 http://dx.doi.org/10.1016/j.rser.2014.09.037

\title{
Harvesting techniques applied to microalgae: a review
}

Ana I. Barros, Ana L. Gonçalves, Manuel Simões, José C.M. Pires *

LEPABE, Departamento de Engenharia Química, Faculdade de Engenharia, Universidade do Porto, Rua Dr. Roberto Frias, 4200-465 Porto, Portugal.

*Corresponding author

Telephone: +351225082262

Fax: +35122508 1449

E-mail address: jcpires@ @e.up.pt 


\begin{abstract}
Research studies on microalgae have increased in the last decades due to the wide range of applications associated to these photosynthetic microorganisms. Microalgae are an important source of oils and other biomolecules that can be used in the production of biofuels and high-valued products. However, the use of microalgae in these green processes is still not economically viable. One of the main costs associated to microalgal production is related to the harvesting process, as it usually accounts for about $20-30 \%$ of total cost. Therefore, this review focuses on the main harvesting processes applied to microalgae, presenting the main advantages and disadvantages of each method, to allow the selection of an appropriate procedure to effectively separate microalgal biomass from the culture medium. To reduce the associated costs, it is common to harvest microalgae in a two-step separation: (i) thickening procedures, in which microalgal slurry is concentrated to about $2-7 \%$ of total suspended solids; and (ii) dewatering procedures, which result in the concentration of microalgal slurry to $15-25 \%$ of total suspended solids. Selection of the adequate harvesting methods depends on the characteristics of the target microorganism and also on the type and value of the end product.
\end{abstract}

Keywords: Bioenergy production; Economic viability; Green processes; Harvesting processes; Microalgae; Sustainable processes. 


\section{Outline}

1. Introduction

2. Microalgal harvesting methods

2.1. Screening

2.2. Thickening

2.2.1. Chemical coagulation/flocculation

2.2.2. Auto and bioflocculation

2.2.3. Gravity sedimentation

2.2.4. Flotation

2.2.5. Electrical based processes

2.3. Dewatering

2.3.1. Filtration

2.3.2 Centrifugation

3. Research needs

4. Conclusions 


\section{Introduction}

It is well known that microalgae have a huge potential in a wide variety of applications. Concerning environmental ones, microalgae can play an important role in bioremediation of wastewater and carbon dioxide sequestration [1-6]. Furthermore, these photosynthetic microorganisms have been considered as a potential renewable fuel source [7-9]: they can be used as raw material for the production of biodiesel, biomethane, bioethanol, biohydrogen and biobutanol. These biofuels are viewed as the most promising alternative to fossil fuels, being able to provide up to $25 \%$ of global required energy [9-11]. One of these energetic products is $3^{\text {rd }}$ generation biodiesel obtained from the transesterification of microalgal lipids, which, in appropriate culture conditions, may represent a significant fraction of their biomass [5, 7, 9, 11-13]. Microalgal based biofuels present numerous economic and ecological advantages comparing to the terrestrial crop based ones: (i) continuous growth in waters with a wide range of salinities and chemical compositions; (ii) growth in any location (arable and non-arable land) without the need for herbicides or pesticides; and (iii) high specific production yields and photosynthetic efficiency [5, 8-11, 14]. Residual biomass, which is poor in lignin and very rich in proteins and other compounds of commercial interest, can then be used in animal feed production and in the synthesis of different high-valued compounds, such as nutritional supplements, cosmetics and pharmaceuticals in a biorefinery-based production [9, 11, 15-19].

Despite the wide range of applications, microalgal production is not economically viable yet. Several research pathways have been explored to improve the economics of the process $[10,20]$. Firstly, microalgae may be cultivated using wastewater as culture medium. This approach aims to reduce both production costs and freshwater requirement. Microalgae have the ability to grow on these environments, assimilating nutrients and metals from the wastewater [9, 21]. Hence, microalgae would play an important remediation role during the tertiary wastewater treatment phase [9]. Secondly, a biorefinery-based production is a strategy that lowers the overall production costs by taking credit of all products of commercial interest that can be obtained from microalgae [7, 9]. Finally, a low cost harvesting process should be studied, as this production step represents $20-30 \%$ of the biomass production costs [9, 10, 22-24]. The main reasons for high process costs are the small size of microalgae and their growth in very dilute cultures (mass concentration less than $1 \mathrm{~g} \mathrm{~L}^{-1}$ ) with densities close to that of the water $[22,23]$. In addition, microalgal surface is negatively charged and the cells carry algogenic organic 
matter (AOM), which keeps stable their dispersed state [25]. At this moment, there is no microalgal harvesting method that is both economically viable and efficient. Lowering harvesting costs is thus considered a key factor for the development of sustainable fullscale production of microalgal biomass [10]. Accordingly, this study aims to review the recent research concerning harvesting methods applied to microalgae, discussing their advantages and disadvantages in terms of applicability, environmental impacts and costeffectiveness.

\section{Microalgal harvesting methods}

An ideal harvesting process should be effective for the majority of microalgal strains and should allow the achievement of high biomass concentrations, while requiring moderate costs of operation, energy and maintenance [22]. The initial harvesting stage is generally costly and determines the following downstream processing. One of two methodologies is generally applied: (i) a two-step concentration where the suspension is primarily thickened to a slurry of about $2-7 \%$ of total suspended solids, TSS, (concentration factor of 100-200) and further dewatered to a cake with 15 to $25 \%$ TSS (concentration factor of 2-10); or (ii) a single-step concentration process [26, 27]. Selection of an appropriate harvesting method depends on the end product, namely its value and properties [23]. Therefore, one must consider the acceptable level of moisture, salt concentrations, cell damage and strain features, such as their density and size. Furthermore, selection of an appropriate harvesting procedure must take into account that microalgal biomass must be further processed. Therefore, these procedures must not be toxic or contaminate microalgal biomass. It is also desirable that the selected harvesting method allows the recycling of the culture medium [27]. For almost applications, microalgal harvesting generally comprises the two-step concentration method: thickening and dewatering (see Figure 1). These stages are crucial to obtain thick algal slurry from the initial suspension and to enable further downstream processes [28, 29].

Microalgal harvesting currently involves mechanical, chemical, biological and, to a lesser extent, electrical based methods. It is very common to combine two or more of these methods to obtain a greater separation rate at lower costs. In fact, the combination of flocculation-sedimentation with centrifugation can significantly reduce process costs [30]. Biological approaches are emerging techniques that can lead to further reduction of operational costs. Mechanical methods are the most reliable and therefore the most 
commonly used to harvest microalgal biomass [10, 23]. However, these methods are often preceded by a chemical or biological coagulation/flocculation thickening stage to improve effectiveness and to reduce operation and maintenance costs. Table 1 presents the main advantages and disadvantages of the most commonly used methods for microalgal harvesting that are described in the following sections.

\subsection{Screening}

Screening is an operation method applied as pre-processing of microalgal cultures. Its efficiency depends on the spacing between the screen openings and cell size [31]. Microstrainers and vibrating screens are the primary screening used devices. In microstraining, a rotary drum is covered with a straining fabric, stainless steel or polyester, and suffers frequent backwash [27]. The flow-through rate is the most determinant factor to overall production costs. Larger microalgae will be effectively processed with larger openings, thus resulting in faster flow rates and lower operational costs. Despite the simplicity of the method and low investment, given the wide character of the mesh that can be used, its efficiency in recovering bacterialsized microalgae is very low and further processing is required [31]. Additionally, there is bacterial and microalgal biofilm formation on the fabric or mesh, which implies constant maintenance. Microstraining is largely influenced by initial microalgal concentration and incomplete solids removal can occur [27]. For instance, Coelastrum proboscideum harvested by this method resulted in $1.5 \%$ TSS consuming $0.2 \mathrm{kWh} \mathrm{m}^{-3}$, while the use of vibrating screens in continuous and batch mode allowed the recovery of 5-6\% TSS and 7-8\% TSS, respectively [32]. One can thereby conclude that greater algal solid content is achievable by vibrating screens, which are also more area efficient [31]. In fact, the harvesting of larger algae, such as Spirulina sp., resulted in $8-10 \%$ TSS with a flow rate of $20 \mathrm{~m}^{3} \mathrm{~h}^{-1}$ [33]. This operation unit is currently used in the commercial production of multicellular filamentous blue-green algae [31].

\subsection{Thickening}

To increase solid concentration of the microalgal suspension and to reduce the volume to be processed, thickening methods must be applied, since volume reduction contributes to considerable savings along the downstream processes [31]. Typically, thickening 
processes consist in coagulation/flocculation (both chemical and biologically based), gravity sedimentation, flotation or an electrical approach to these [27].

\subsubsection{Chemical coagulation/flocculation}

Chemical coagulation/flocculation is the main approach towards the economical optimization of microalgal harvesting processes. Application of these methods is required mostly due to the large volumes of microalgal cultures that must be processed and to the need for a universal method that can be applicable to a wide variety of species [27]. This harvesting step is used to concentrate the suspension 20-100 times [19]. It increases the effective particle size, prior to dewatering, thus significantly reducing its energy demand [23, 34]. For low cost harvesting of microalgae, coagulation/ flocculation is generally followed by gravity sedimentation [35].

Whereas coagulation involves $\mathrm{pH}$ adjustment or electrolyte addition, flocculation is based on the addition of cationic polymers to the broth [16]. In this way, chemical coagulation/flocculation can be defined as the coalescence of finely divided particles in suspension onto larger aggregates followed by the agglomeration of these into larger flocs that settle to the bottom of the vessel, leaving a clear supernatant. Flocculation can be induced by different ways: (i) electrostatic patch (or patching), which occurs when a charged polymer binds to an opposite charged particle, locally reversing that charge and creating a patch that will connect with opposite charged patches; (ii) bridging, which occurs when polymers or colloids bind to the surface of two different particles forming a bridge between them; and (iii) sweep flocculation, which occurs when particles are entrapped in a massive mineral precipitation [19]. Cellular concentration and surface properties, namely net charge and hydrophobicity, concentration of the coagulant/flocculant species, as well as $\mathrm{pH}$ and ionic strength of the broth are key factors that influence this process [16]. Microalgal growth phase also influences flocculation, as $\mathrm{pH}$, dissolved $\mathrm{CO}_{2}$, zeta potential and particle size suffer significant variations throughout the cultivation time [36]. Therefore, it is advantageous to consider the stationary phase to harvest microalgal biomass. In this phase, microalgae have lower metabolic activity and cell mobility, presenting higher intercellular interactions, as the zeta potential is lower. This is also observed by the higher particle size, which may be due to cell agglomeration. Storage conditions before harvesting are preponderant as well. The presence of daylight enables photosynthesis and thus higher metabolic rate and unicellular mobility, resulting 
in lower settling rates [22]. Ideally, chemical coagulation/flocculation should: (i) result in no biomass contamination; (ii) lead to subsequent high efficiency biomass settling; (iii) allow the reuse of the culture medium; (iv) consider environmental impact; and (v) be cheap and non-toxic when applied in large scale [23].

A wide variety of salts has been tested as coagulants for microalgal harvesting. Multivalent metal salts, such as $\mathrm{FeCl}_{3}, \mathrm{Al}_{2}\left(\mathrm{SO}_{4}\right)_{3}$ and $\mathrm{Fe}_{2}\left(\mathrm{SO}_{4}\right)_{3}$, have been effectively tested, as it is shown in Table 2. Dissociation of these salts in the culture medium lowers electrostatic repulsion between the negatively charged cell surfaces, enabling cell aggregates formation $[9,16]$. The activity of an ion is largely determined by its electronegativity: the more electronegative the ion, the faster the coagulation (under 24 h) [16]. Solubility is also a key factor: salts with lower solubility are more effective. For example, chloride salts are more efficient than the equivalent sulphate ones, due to their lower solubility. Furthermore, the higher the charge density of an ion, the more efficient the charge neutralization between microalgal cell surfaces is expected to be. Finally, pH has to be low enough to form cationic hydrolysis products, which are crucial in coagulation, since this method functions by charge neutralization [27].

As to all harvesting methods, selection of the appropriate coagulant is determined by the target of the subsequent processes. The use of ferric salts has shown to lead to a brownyellow coloration of the microalgae. However, no effect on the photosynthetic apparatus and cell viability was observed. In this way, if pigment extraction is intended, ferric salts cannot be applied. On the other hand, if the aim is to reduce the overall production cost, a cheaper and faster coagulant, such as an aluminium salt should be applied. When using aluminium salts, cell lysis was observed (10 to $25 \%$ ), possibly due to rapid cell aggregation or cell membrane destabilization [16]. Despite being easily flocculated by metal coagulants, such as alum and iron chloride, large amounts of these salts are required, making it a very expensive option [34]. Furthermore, microalgal biomass treated with these chemical species can be contaminated by the used metals, hindering its application as biofuel or animal feedstock [37].

Although coagulation/flocculation followed by gravity sedimentation is a cheap approach for microalgal harvesting, coagulant costs represent a significant portion of the overall process (4 to $7 \%$ ). Therefore, the use of naturally available coagulants/ flocculants, such as phosphates, carbonates, calcium and magnesium ions, frequently found in wastewater, brackish water or seawater, has been considered [35]. However, phosphate based 
coagulation is only feasible for phosphate rich wastewater, since when added to a free medium, microalgae hoard it in addition to their metabolic uptake. On the other hand, the use of magnesium ions as coagulants may be advantageous, as they present similar efficiencies to those achieved with $\mathrm{Al}^{3+}$ and $\mathrm{Fe}^{3+}$ ions and can be easily obtained from wastewaters. Additionally, the coagulation efficiency can also be enhanced through lime addition to the culture broth $[30,35]$. The mechanism of coagulation by magnesium is thought to begin with charge neutralization at the cell surface that, with further hydroxide precipitation, leads to sweep flocculation [35]. Limestone or dolomites can be applied, as they bring not only magnesium ions but also other carbonates, hydroxides and oxides, which present $\mathrm{pH}$ related coagulating activity as well $[30,35]$.

The relationship between coagulant dose and microalgal cell concentration is not clear, as it has been reported as being linear [16, 38], as well as proportional to the cell concentration logarithm. Nonetheless, high density cultures require almost 10fold less coagulant addition than expected. This might be due to the presence of less charged material on the surface of cell walls or to the shorter distance between cells that leads to higher collision rates [30]. Coagulant dose is also greatly influenced by AOM produced and excreted by microalgal cells. Excretion of AOM affects flocculation by alum, chitosan and cationic starch addition, as well as pH-induced flocculation. AOM is mainly constituted by extracellular polymeric substances (EPS), normally of polysaccharide or proteic nature. Proteins form complexes with the metal ions of most chemical coagulants and polysaccharides (with negatively charged carbonyl groups) interact with the positively charged coagulants, both making them unavailable microalgal flocculation. Nevertheless, the number and position of the carbonyl groups on the polysaccharides differ with microalgal species and cultivation conditions, showing different influence upon flocculation [34]. For instance, nutrient-limited cells (conditions that maximize lipid yield) generate more AOM than exponential growing ones. The ionic strength of the broth also influences the coagulant dose required. For example, the flocculation of marine microalgae demands five to ten times more coagulant dose than that of freshwater ones, since the chemical activity of the coagulant is reduced by the presence of marine salts [27].

Polyelectrolyte flocculants are natural or synthetic polymers of ionic or non-ionic species. The use of polymeric materials allows the reduction required dose by increasing their molecular weight [27, 39]. Nevertheless, the presence of some chemical substances and 
$\mathrm{pH}$ of the medium are crucial to effective flocculation. These flocculants can either be cationic, anionic or non-ionic. However, due to the negative net charge of microalgal cells, anionic or non-ionic polymers have no effect on their flocculation [27]. Some cationic polymers, such as chitosan, cationic polyacrylamides, cellulose, surfactants and other man-made fibers proved to have successful flocculating activity towards microalgal cultures [31]. Cationic polymers reduce microalgal cell surface electronegativity and bridge them to one another [23]. These methods are effective in the flocculation of freshwater microalgae; however, the high salinity of the marine environment can be inhibitory, as the polymers shrink to smaller dimensions, failing in bridging the cells $[23,30]$. This effectiveness reduction to flocculate marine microalgae is attributed to the ionic strength of sea and brackish waters [27]. Effective polyelectrolyte flocculation can be employed only when the salinity level is lower than $5 \mathrm{~g} \mathrm{~L}^{-1}$. Polyelectrolytes, such as polyacrylamide, cannot be used to harvest microalgae, due to its toxicity. Chitosan has been effectively used in the harvesting of both fresh and seawater microalgae and does not contaminate microalgal biomass; however it is too expensive for large scale applications [30]. An alternative to chitosan is cationic starch, which is less $\mathrm{pH}$-dependent, but requires higher dosage [39]. In order to improve its effectiveness, cationic starch must be designed to have more substitutions. Nonetheless, this would increase the polymer production cost.

\subsubsection{Auto and bioflocculation}

Despite being different phenomena, it is common to refer to auto and bioflocculation as being the same concept. Autoflocculation (flocculation merely by $\mathrm{pH}$ increase) is an attractive alternative, as it is low cost, low energy, non-toxic to microalgae and does not require the use of flocculants, enabling simple medium reuse [40]. This process may occur naturally in microalgal cultures exposed to sunlight (in warm and sunny days) with limited $\mathrm{CO}_{2}$ supply $[19,41]$ : through photosynthesis, microalgae remove $\mathrm{CO}_{2}$ dissolved in the culture medium, increasing its $\mathrm{pH}$ value. Magnesium and calcium hydroxide have been used to study autoflocculation (Table 3). This phenomenon can also be simulated by the addition of $\mathrm{NaOH}$, which is a low cost product $[19,40]$. Horiuchi et al. [40] flocculated Dunaliella tertiolecta by adding a $\mathrm{NaOH}$ solution. The settling time was very short (few minutes) with a $\mathrm{pH}$ value between 8.6 and 10.5, resulting in a biomass recovery efficiency above $90 \%$. High $\mathrm{pH}$-induced flocculation may have further advantages when applied to microalgal cultures in wastewaters, due to its negative effect on pathogenic 
microorganisms [34]. Additionally, autoflocculation has greater influence in the recovery of marine microalgae rather than in the recovery of freshwater ones [42]: under high $\mathrm{pH}$ values, ions present in seawater react producing chemical formations that lead to changes on microalgal cell surfaces and consequent acceleration of their settling. Studies using ammonia to alter the $\mathrm{pH}$ of the culture broth have suggested the existence of a $\mathrm{pH}$ threshold above which the process becomes more efficient. $\mathrm{pH}$ induced flocculation mechanisms were thought to be affected by the balance between electrostatic repulsion and van der Waals attraction (reducing or neutralizing microalgal surface cell charge in response to an increase in the ionic strength of the culture medium). However, some studies currently indicate that an increase in $\mathrm{pH}$ generates precipitation of magnesium hydroxide, calcium hydroxide [34], calcium phosphate and other insoluble particles that cover the cell surface. This, in combination with charge neutralization or adhesive attraction, results in heavier flocs and, therefore, more stable settling [42]. Despite their advantages, these methods are not preferred at industrial scale for pre-concentration of microalgae, as they are not reliable for controlled flocculation and cause changes in cell composition [24].

Bioflocculation relates to microalgal flocculation caused by secreted biopolymers, especially by EPS [10]. Flocculants produced by bacteria can be an important economical step towards sustainable microalgal based biofuel production. Bioflocculation eliminates the need for chemical flocculants, which represent an expensive, non-feasible and toxic alternative. However, co-culture of microalgae with bacteria, fungi or flocculating microalgae results in microbiological contamination, interfering with food or feed applications of microalgal biomass [19]. In the case of biofuel production, the added microorganisms may even contribute to the increase in lipid yields. [24, 43]. Resulting culture media from these methods can also be effectively reused, thus significantly reducing microalgal cultivation costs [44]. The success of microbial flocculation depends on the production of EPS by the bacteria in high concentrations and the ability of microalgae to attach to them to form flocs [37].

Microbial flocculants have been widely used for wastewater treatment, as the wastewater can provide the necessary carbon source for flocculating microorganisms [19]. In fact, a large amount of common soil bacteria excrete mucous material with potential flocculation activity. In the study performed by Oh et al. [43], Paenibacillus sp. showed the highest flocculant activity (Table 4). However, to be effective, the produced flocculant needed 
the addition of chemical flocculants, such as $\mathrm{CaCl}_{2}$. Although this method reduces the amount of chemical coagulant needed for efficient flocculation, it is not ideal. Nonetheless, a bioflocculant produced by Solibacilus silvestris was reported to be effective in flocculating microalgae without the addition of chemical coagulants. This bioflocculant is a significant improvement from earlier ones, since it can be recycled losing only $3 \%$ of flocculation efficiency and it is innocuous to microalgal cells [45].

Microalgal bacterial flocs (MaB flocs) are aggregations of these microorganisms able to settle quicker than microalgae alone, due to their larger size [46]. Both microalgae and bacteria produce EPS that are indistinguishable from one another. Furthermore, these polymers are responsible for cell adhesion without cell stress or lysis over an extended period [47]. However, it appears that the presence of these microorganisms is required for a predictable flocculation method [47, 48]. In fact, some bacteria from the genera Flavobacterium, Terrimonas and Sphingobacterium, which are frequently associated to microalgal growth, have shown a collective role on harvesting the microalga Chlorella vulgaris. Flocs formed in these xenic cultures presented diameters of about $100 \mu \mathrm{m}$, which resulted in higher sedimentation and flocculation ability (Table 4) when compared to axenic C. vulgaris flocs $(20 \mu \mathrm{m})$. Also, the addition of the bacterial broth to the microalgal culture in a later growth stage showed a greater flocculation efficiency than the axenic culture, proving that both bacterial cells and bacterial extracellular metabolites play an important role in the process [48]. Lower substrate concentration seemed to be related to the formation of denser flocs with a large number of microalgal cells embedded. However, the recovery efficiency remained similar [47]. Typical MaB flocs present a diameter of 148 to 305 $\mu \mathrm{m}$ and the carbon source has a clear effect on its settleability. In cultures using an inorganic carbon source, filamentous cyanobacteria, such as Phormidium sp., tend to dominate, resulting in poor settling flocs [49].

Flocculation of microalgae by adding bacteria may require the addition of extra organic substrate and energy source to enable their growth. This will potentiate the incidence of bacterial and fungal contaminations upon microalgal cultures. In this way, the harvesting of non-flocculating microalgae by adding a flocculating species appears as a promising alternative method. This method enables total broth reuse, as it does not require the addition of chemicals. Also, it does not require different cultivating conditions, resulting in further savings. Furthermore, the addition of flocculating microalgae does not interfere with later downstream processing of the lipids into biodiesel. The only reason why these 
microalgae are not used for biodiesel production in the first place is their low lipid contents [24]. Studies suggest that the mechanism of this flocculation method is both bridging and patching: when a large network of cells is formed the mechanism involved is bridging, while if the cells seem more closely attached, the mechanism involved may be patching by the EPS excreted from flocculating microalgae. Recovery efficiencies, as well as the time needed for microalgal sedimentation, are in the same range as the ones observed for chemically induced flocculation (Tables 2 and 5). Considering a raceway pond cultivation system of 100 ha and a disk stack bowl centrifuge, the application of this pre-concentrating method, with a ratio between flocculating and non-flocculating microalgae of 0.25 , generates an energy saving per biomass dry weight of approximately $12 \mathrm{MJ} \mathrm{kg}_{\text {dry weight }}{ }^{-1}[50]$.

Microalgal/fungi association occurs naturally in lichens. Symbiotically, microalgae fix $\mathrm{CO}_{2}$ and produce organic compounds, promoting fungal growth, which, in return, entrap the microalgae by hyphae production $[44,51]$. Fungal assisted microalgal flocculation is effective for both heterotrophic and autotrophic microalgal species. Some filamentous fungi, for instance, Rhizopus oryzae, Penicillium expansum and Mucor circinelloides, were reported to form pellets with 2 to $5 \mathrm{~mm}$ of diameter. The use of fungi for pelletization has already been successfully applied in wastewater treatment, where they are used to entrap the sludge solids [52]. Furthermore, some fungal species were reported to have lipid contents of over $30 \%$ of total biomass, making them suitable for biodiesel feedstock along with the microalgal biomass [51]. Additionally, as the previous one, this flocculation technique does not require different cultivation conditions and allows total medium reuse without additional treatment [44]. Xie et al. [53] studied mixed cultures with $C$. vulgaris (fungi-to-algae ratio of 1:2) and observed that $99 \%$ of the biomass was removed after two days of co-cultivation. Besides the reduction of harvesting costs when applying this technology, biomass and lipid yields can be significantly increased. The presence of an organic carbon source along with $\mathrm{pH}$ adjustment to 4.0 to 5.0 seem to favour the process (Table 4) [51]. The harvested pellets have been successfully used for municipal and animal wastewater treatment, presenting higher nutrient removal rates than free microalgal cells. Therefore, this is a suitable way of bioenergy and bioproducts production, while contributing to the effective treatment of wastewaters [44].

\subsubsection{Gravity sedimentation}


Despite the rudimental character of the process, sedimentation works for various types of microalgae and is highly energy efficient [9]. Thus, when the end product has extremely low value, such as biofuels, gravity sedimentation should be selected for microalgal harvesting $[9,23]$. Since microalgal density is a key to ensure the process efficiency, the reliability of this method is low. Microalgal settling rates of $0.1-2.6 \mathrm{~cm}$ $\mathrm{h}^{-1}$ result in a very slow sedimentation process that leads to the deterioration of most of the biomass during the settling time, limiting the application of this method for routine harvesting [10]. In this way, to fasten microalgal settling, it is common to apply a coagulation/flocculation step prior to gravity sedimentation [23, 54, 55].

The best results of microalgal harvesting using gravity sedimentation were achieved through lamella-type separators (recovery of 1.6\% TSS) and sedimentation tanks (recovery of 3\% TSS) attributable to microalgal autoflocculation [31]. The use of sedimentation tanks is viewed as a simple and inexpensive process, but the concentration achieved is very low without previous coagulation/flocculation. In the same way, microalgal concentration by lamella-type separators is low and unreliable, requiring further thickening.

\subsubsection{Flotation}

Flotation is often defined as "inverted" sedimentation where gas bubbles fed to the broth provide the lifting force needed for particle transport and separation. This process is commonly applied in wastewater treatment processes and is often preceded by coagulation/flocculation [56]. Given microalgal low density and self-float characteristics, flotation is more effective and beneficial in microalgal removal than in sedimentation [57]. Microalgae such as Microcystis sp., which are often associated to wastewater, have a very reduced size $(3-7 \mu \mathrm{m})$, requiring a pre-coagulation/ flocculation step in order to produce aggregates of at least $10 \mu \mathrm{m}$, feasible of flotation recovery [56]. The major advantage of flotation is that it has been proved at large scale although it generally requires the use of flocculants [57]. Further advantages of flotation are low space requirements, relatively short operation times and high flexibility with lower initial equipment costs [56].

The success of flotation can be described as a product of two probabilities: (i) bubble-particle collision; and (ii) bubble-particle adhesion after a collision has occurred. In this way, it depends on the instability of the suspended particle, lower instability will result in 
higher air-particle contact, and on particle size, the smaller they are, the more likely they are to be levitated by the bubbles [27, 31]. Particles in suspension must be hydrophobic, in order to attach to gas bubbles [57]. Flotation has been successfully applied in the separation of freshwater microalgae, such as $C$. vulgaris, and it is a promising low cost large scale harvesting method [58]. On the other hand, flotation of marine microalgae may be compromised, as salinity is a key factor for bubble-cell adhesion [58, 59]. Under high ionic strength, gas bubbles were reported to be larger and with tendency to rupture more easily. At controlled $\mathrm{pH}$, an increase in ionic strength of the medium results in a decrease of flotation efficiency from $90-92 \%$ to $32 \%$ [58]. In this process, coagulation can be applied, by suppression of the electrical double layer, leading to floc formation [57]. Microalgal removal depends on recycling rate, air tank pressure, hydraulic retention time and particle floating rate, while the concentration of the produced slurry depends on skimmer velocity and relative positions towards the surface of the water [27].

Presently, there are four main flotation techniques: (i) dissolved air flotation (DAF bubble diameter $<100 \mu \mathrm{m}$ ); (ii) dispersed air flotation (DiAF - bubble diameter 100-1000 $\mu \mathrm{m}$ ); (iii) electrolytic flotation; and (iv) ozonation-dispersed flotation (ODF) [9, 31, 54, 55]. DAF is the most efficient and widely employed option: this process requires dissolving air in water at very high pressure, so that the solution becomes supersaturated, leading to nucleation of bubbles when the pressure is reduced in the nozzle. The bubbles then float to the surface carrying the suspended solids that later can be skimmed off. In this way, DAF is very energy intensive. It is convenient to recycle a portion of the clarified liquid and saturate it with air to provide bubble flux [27]. On the other hand, DiAF generates bubbles by passing air continuously through a porous material. This process consumes less energy, but requires more expensive equipment and demands higher pressure drop for bubble generation. Electro-flotation depends on the formation of fine hydrogen bubbles by electrolysis [31]. Finally, ODF is a method that creates charged bubbles: as microalgal cells are negatively charged, the mechanism consists in the interaction of the charged bubbles with them [9]. Harvesting of C. vulgaris by this method has shown an increase on its lipid content by $24 \%$ and caused cell lysis. Cell lysis can be beneficial, as it releases to the broth a number of biopolymers that can act as coagulants, thus enabling a more effective separation (Table 5). However, it is a very expensive process that poses contamination problems when applied at large scale. 
Separation of flocs depends on bubble flux and size. Small bubbles have high surface area to volume ratio and low rise velocity, which leads to faster attachment and tender contact with particles. In this way, the use of micro-sized bubbles (microflotation) is a good alternative towards separation of fragile flocs. However, the efficiency of microflotation in microalgal separation strongly depends on $\mathrm{pH}$ and coagulant dosage. This technique must use preferably a fluidic oscillator, since neither DAF nor DiAF are capable of generating the right size bubbles in a sustainable way [57].

\subsubsection{Electrical based processes}

Electrical approaches to microalgal harvesting are not largely disseminated. Nonetheless, these methods are versatile, as they are applicable to a wide variety of microalgal species, while being environmentally friendly (they do not require the addition of chemicals) [27, 60]. As microalgal cells are negatively charged, when an electrical field is applied to the culture broth, the cells can be separated [27]. They can form precipitates on the electrodes (electrophoresis), as well as accumulate on the bottom of the vessel (electro-flocculation). On the other hand, electro-flotation mechanism only differs from DAF in the way of the bubbles are made. Hydrogen bubbles are formed through water electrolysis, which can be cheaper than conventional DAF [31]. The generation of these bubbles can be done at the anode and coupled with the electro-coagulation that occurs through the electrolytic oxidation that happens at the cathode [61]. This process is described as electro-coagulation-flotation (ECF) [61].

Two types of electrodes can be applied: sacrificial and non-sacrificial [27]. The use of sacrificial electrodes results in metal ions being released to the broth, depending on the amount of electricity that passes through the electrolytic solution [27, 60]. The dissolution of the released ions from the reactive anode results in coagulant formation that destabilizes the microalgal suspension. Consequently, microalgal cells aggregate by combining with the positively charged metal ions [27]. This electrode dissolution is not comparable, toxicity wise, with the addition of chemical coagulants [60]. In this way, the probability of contamination with metallic hydroxides is significantly lowered for both methods [27]. The use of a non-sacrificial electrode is based only on the movement of the negatively charged microalgae towards the anode. Upon reaching the anode, cells lose their charge forming aggregates. Thus, this type of equipment is very prone to fouling when compared to chemical methods. Electrical based methods are largely influenced by 
the material by which the electrodes are made. Aluminium and iron are the most commonly used metals in this type of process. Considering an harvesting period of 45 min, while an aluminium electrode performed a total removal efficiency (100\%), an iron one only achieved a removal of $78.9 \%$, mainly because these electrodes have less current efficiency and dissociate less than the aluminium ones. Hence, ferric electrodes are not convenient, as they consume more energy and result in brown coloured slurry, due to ferric oxide formation, the opposite from aluminium electrodes.

Current density deeply affects the reaction kinetics, showing a great influence in the harvesting efficiency, as well as in the energy consumption of the operation. The increase in current density results in shorter harvesting periods [61]. This can be attributed to the fact that the formation of aluminium ions by oxidation at the anode increases with current density and electrolysis time. High ion concentration increases coagulant surface area and active binding sites, promoting microalgal floc formation. However, while microalgal harvesting using a current density of $0.5 \mathrm{~mA} \mathrm{~cm}{ }^{-2}$ required an energy consumption of $0.2 \mathrm{kWh} \mathrm{m}^{-3}$, when a current density of $5.0 \mathrm{~mA} \mathrm{~cm}$ - was applied, energy consumption increased to $2.28 \mathrm{kWh} \mathrm{m}^{-3}$ [61]. Thus, despite the achievement of higher harvesting efficiencies with higher current densities, a balance must be set between the harvesting period and the energy consumption. Further optimization can be done by stirring the mixture in order to increase the probability of particle contact and therefore overcome the electrical double layer that prevents their aggregation. Electro-flocculation followed by mixing and settling lowers the energy requirements for microalgal harvesting. It requires higher operation times and results in a final slurry with a low concentration. On the other hand, electro-flocculation followed by flotation results in higher concentrations and energy requirements with lower processing times [62]. Particle collision and transport rate can also be increased by increasing process temperature [61]. Considering the ECF process time of $15 \mathrm{~min}$, an increase in temperature from 18 to $36^{\circ} \mathrm{C}$ resulted in an increase from 46 to $98 \%$ in the process recovery. Electrolysis time can also be shortened by increasing process temperature, as it improves the dissolution rate of aluminium. Therefore energy consumption of the electrolysis process can be lowered from 0.36 to $0.16 \mathrm{kWh} \mathrm{m}^{-3}$, considering the same temperature range.

Broth properties, such as $\mathrm{pH}$ and initial cell concentration, can offer resistance to cell motion towards the electrodes [31, 61]. It is known that seawater microalgae are more easily separated and require approximately half the energy consumption than the 
harvesting of freshwater species, as the low ionic strength of the culture medium hinders the separation process [60]. In the same way, the initial $\mathrm{pH}$ of the medium influences microalgal cell recovery, as it determines the type of aluminium ions formed. In a $\mathrm{pH}$ range of 4 to 7 , the formed species are aluminium hydroxide, monomeric hydroxoaluminum cations and polymeric species such as $\mathrm{Al}_{13} \mathrm{O}_{4}(\mathrm{OH})_{24}{ }^{7+}$. Hence the negatively charged microalgal cells are easily absorbed onto these positively charged precipitates, facilitating the harvesting process. On the other hand, in alkaline conditions, monomeric hydroxoaluminum anions dominate the solution, reducing the adsorption capacity of microalgal cells. In these conditions, efficient harvesting can only be achieved by increasing the electrolysis time, resulting in microalgal flocculation by sweeping and enmeshment mechanisms. Initial cell density does not strongly affect the energy consumption for complete microalgal removal. Nevertheless, microalgal recovery significantly decreases with the increase of initial cell density, as no sufficient aluminium is available for the removal of the excessive cells with short electrolysis time. While total recovery was achieved in only $25 \mathrm{~min}$ for an initial cell concentration of $0.55 \times 10^{9}$ cells $\mathrm{L}^{-1}$, the same was only possible in $75 \mathrm{~min}$ for an initial cell concentration of $2.10 \times 10^{9}$ cells $\mathrm{L}^{-1}$ [61].

Despite these electrical methods present several advantages, energy requirements and equipment costs remain too high for sustainable large scale application at the time [10]. One must consider the scaling up of the electrodes and its effect on the optimization of operation parameters, such as $\mathrm{pH}$, temperature, stirring, distance between the electrodes and their surface area.

\subsection{Dewatering}

Dewatering of the microalgal slurry is achieved by various mechanical means, including various types of filtration and centrifugation. After harvesting, the dewatered cake is usually dried to improve the efficiency of the downstream processes (e.g., lipid extraction).

\subsubsection{Filtration}

Filtration is mainly a dewatering means and it is normally applied following coagulation/flocculation to improve harvesting efficiency. Its application requires the maintenance of a pressure drop across the system to force fluid flow through a membrane. 
In this process, microalgal deposits on the filtration membrane tend to grow thicker throughout the process, increasing resistance and decreasing filtration flux upon a constant pressure drop [31]. This phenomenon (called fouling/clogging) represents the main drawback associated to filtration methods, increasing their operational costs [10]. Critical flux is defined as the lowest flux that creates irreversible deposit on the membrane. However, limiting flux represents the maximum stationary permeation flux that can be reached, for a given tangential velocity, by increasing transmembrane pressure. Therefore, with the purpose of optimizing performance and minimize cleaning steps, it is necessary to work in the sub-critical zone. Nevertheless, even working at these conditions, gradual minor fouling can occur followed by a drastic increase that requires chemical cleaning. This phenomenon is further affected by the production of EPS, commonly secreted by microalgae when in stress conditions. These substances cause a gel-like layer in the filtration cake, increasing the resistance to flow, also requiring chemical cleaning to be eliminated [63]. Membranes must then be regularly cleaned to ensure sanitization and reusability.

Filtration is only sustainable for harvesting long length microalgae or those forming large colonies [51]. Despite microalgal cells of very low densities can be harvested by this method (a major advantage), membrane filtration is not commonly applied in large scale processes [23]. Both tangential flow and dead-end filtration modes can be applied. Also, different methods can be applied upon the required pressure drop, namely gravity, pressure, vacuum, or magnetic filtration [31, 64]. Dead-end filtration is effective in the recovery of large microalgal cells (diameter over $70 \mu \mathrm{m}$ ) [9, 23]. Tangential flow filtration (TFF) is considered more appropriate for the harvesting of smaller suspended algae due to minor fouling problems (Table 6) [10, 25]. Furthermore, this method allows the separation of shear sensitive suspensions [27]. As the medium flows tangentially across a membrane and the retentate is recirculated, the cells are kept in suspension, thus reducing membrane fouling. TFF has a better anti-fouling performance, given the deposit removal effect caused by the high fluid velocity tangential to the membrane [65]. Additionally, higher filtration rates can be achieved, enabling complete removal of microalgal cells and debris. Micro- or ultrafiltration membranes tend to be costly, energy intensive and need frequent membrane replacements [9]. Microfiltration (pore size from 0.1 to $10 \mu \mathrm{m})$ is suitable for harvesting fragile smaller cells. These membranes allow higher initial fluxes, but clog more easily [27]. On the other hand, ultrafiltration (pore 
diameter: 1 to $100 \mathrm{~nm}$ ) is appropriate for separation of solutes within 1 to $500 \mathrm{kDa}$ of molecular weight. The performances of both methods rely on hydrodynamic conditions, concentration and culture properties. However, through ultrafiltration and for a long-term operation, low pressure and tangential velocity fluxes similar to other industrial installations for biotechnological applications are achieved. Ultrafiltration also seems to retain all cells and debris, which is convenient for these applications [66]. High gradient magnetic filtration can also be efficiently applied. Biosorption of submicron-sized magnetic particles has great potential on microalgal harvesting. Efficiencies of over $95 \%$ have been reported [67]. These particles must be low cost, reusable, chemically stable and have high adsorption capacity.

Filtration major costs are related with membrane replacement and pumping; thus, it is cost-effective only for small volumes [27]. In fact, microfiltration can be more costeffective than centrifugation when the volume to be processed is less than $2 \mathrm{~m}^{3} \mathrm{~d}^{-1}$. For volumes greater than $20 \mathrm{~m}^{3} \mathrm{~d}^{-1}$, centrifugation may be more economic [23, 66]. The recommended design for pressure filtration, with respect to energy savings, reliability and concentration capability, are chamber filter press, cylindrical sieve and filter basket [31].

\subsubsection{Centrifugation}

Centrifugation is the fastest harvesting method, but also the most expensive due to its high energy consumption, which limits its application to high-valued products, such as highly unsaturated fatty acids, pharmaceuticals and other commodities [9, 10, 23, 51]. Centrifuges are able to harvest the great majority of microalgae [9]. Some are even efficient as one-step separation process, while others require a pre-concentrated algal slurry [31]. However, there are evidences that the exposure of microalgal cells to high gravitational and shear forces results in cell structure damage [28].

Normally, centrifuges are set to maximize capture efficiency. However, cost-effective microalgal harvesting may not coincide with the maximum capture efficiency [20]. To achieve high harvesting efficiencies, longer retention times in the bowl are needed to enable their sedimentation, due to the small size of these cells. High cell removal efficiency (94\%) and low flow rate $\left(0.94 \mathrm{~L} \mathrm{~min}^{-1}\right)$ implied a $20 \mathrm{kWh} \mathrm{m}^{-3}$ of culture water energy input, whereas only $0.80 \mathrm{kWh} \mathrm{m}^{-3}$ was needed for a $17 \%$ recovery at a flow rate of $23 \mathrm{~L} \mathrm{~min}^{-1}$. In this way, while high capture efficiency (slower flow rates) required more energy per volume of culture, lower recoveries were offset by the increase in the 
processed volume. This low energy conditions result in a decrease in overall cost per litter of produced oil (Table 7) [20]. If coagulation/flocculation is applied prior to centrifugation, its high energy consumption might be lowered, as it reduces the volume to be processed in $65 \%$. Additionally, this combination resulted in a 3.8 fold increase in final algal concentration [30].

\section{Research needs}

The optimization of a pre-concentration step before the dewatering process is the most promising approach towards lowering microalgal harvesting costs. At the same time, environmental sustainability must be taken into account. Regarding biologically based harvesting methods, better understanding and control of auto and bioflocculation processes could improve their performance and reduce operational costs. Biological production of flocculants shows great potential, given the absence of microbial and chemical contamination. Nevertheless, little is known about which molecules have these properties, which microorganisms produce them and how they do it. On the other hand, the effect of co-cultivation of flocculating microorganisms and oil producing microalgae on their growth kinetics is yet to be accessed. If a favourable relationship exists, this method should also be further explored, given its cheapness and convenience of application. Manipulating microalgal characteristics through genetic engineering is also of importance. Clear identification of the mechanisms that allow some microalgal species to autoflocculate in a predictable way is imperative. These could then be genetically engineered onto high oil bearing species allowing the development of a reliable bioflocculation method. Other alternative may be the incorporation of the microalgal lipid overproduction apparatus onto microorganisms that are more commonly used in large scale operations, such as Escherichia coli and Saccharomyces cerevisiae, easing the scale up of all the processes related to biodiesel production, including biomass harvesting. Electrical approaches also present a high potential towards energetic optimization of microalgal harvesting, but the effect of the scale up of these methods should be determined. A low cost reliable method for pre-concentrate microalgal cultures is yet to be developed.

\section{Conclusions}


The harvesting methods described in this review constitute efficient ways to recover microalgal biomass from the culture medium. However, there is not a universal method that can be applied to harvest all microalgal strains with the same efficiency. An efficient method should be designed basing on microalgal properties, such as cell morphology and size and cell surface properties, on the properties of the culture medium and on the quality and value of the end product. Additionally, to improve harvesting efficiencies and costs, it is common to apply a combination of processes. Normally, a two-stage separation, composed of thickening and dewatering processes, is required. Concerning biofuel applications, bioflocculation followed by gravity sedimentation seems to be a costeffective way of microalgal biomass recovery. However, the possibility of microbiological contaminations may limit the application of bioflocculation when the aim of the separation is animal feed or the production of high-valued compounds. Therefore, to avoid the toxicity of chemical coagulants/flocculants and microbiological contaminations from bioflocculation processes, electrical based methods may be the alternative.

\section{Acknowledgements}

Ana L. Gonçalves and José C.M. Pires are grateful to Foundation for Science and Technology (FCT), POPH-QREN and FSE for their fellowships SFRH/BD/88799/2012 and SFRH/BPD/66721/2009, respectively. 


\section{References}

[1] Farrelly DJ, Everard CD, Fagan CC, McDonnell KP. Carbon sequestration and the role of biological carbon mitigation: a review. Renew Sust Energy Rev 2013;21:712-27. [2] Oncel SS. Microalgae for a macroenergy world. Renew Sust Energy Rev 2013;26:241-64.

[3] Pires J, Alvim-Ferraz M, Martins F, Simões M. Wastewater treatment to enhance the economic viability of microalgae culture. Environ Sci Pollut Res 2013:1-10.

[4] Pires JCM, Alvim-Ferraz MCM, Martins FG, Simões M. Carbon dioxide capture from flue gases using microalgae: engineering aspects and biorefinery concept. Renew Sust Energy Rev 2012;16:3043-53.

[5] Rashid N, Rehman MSU, Memon S, Ur Rahman Z, Lee K, Han J-I. Current status, barriers and developments in biohydrogen production by microalgae. Renew Sust Energy Rev 2013;22:571-9.

[6] Razzak SA, Hossain MM, Lucky RA, Bassi AS, de Lasa H. Integrated $\mathrm{CO}_{2}$ capture, wastewater treatment and biofuel production by microalgae culturing - a review. Renew Sust Energy Rev 2013;27:622-53.

[7] Chisti Y. Biodiesel from microalgae. Biotechnol Adv 2007;25:294-306.

[8] Gonçalves AL, Pires JC, Simões M. Green fuel production: processes applied to microalgae. Environ Chem Lett 2013;11:315-24.

[9] Rawat I, Ranjith Kumar R, Mutanda T, Bux F. Dual role of microalgae: phycoremediation of domestic wastewater and biomass production for sustainable biofuels production. Appl Energy 2011;88:3411-24.

[10] Christenson L, Sims R. Production and harvesting of microalgae for wastewater treatment, biofuels, and bioproducts. Biotechnol Adv 2011;29:686-702.

[11] Smith VH, Sturm BS, Denoyelles FJ, Billings SA. The ecology of algal biodiesel production. Trends Ecol Evol 2010;25:301-9.

[12] Gonçalves AL, Pires JC, Simões M. Lipid production of Chlorella vulgaris and Pseudokirchneriella subcapitata. Int J Energy Environ Eng 2013;4:1-6.

[13] Marcilla A, Catalá L, García-Quesada JC, Valdés FJ, Hernández MR. A review of thermochemical conversion of microalgae. Renew Sust Energy Rev 2013;27:11-9.

[14] Atabani AE, Silitonga AS, Badruddin IA, Mahlia TMI, Masjuki HH, Mekhilef S. A comprehensive review on biodiesel as an alternative energy resource and its characteristics. Renew Sust Energy Rev 2012;16:2070-93. 
[15] Becker W. Microalgae in human and animal nutrition. In: Richmond A, editor. Handbook of Microalgal Culture, Oxford: Blackwell Publishing Ltd; 2004. p. 312-51.

[16] Papazi A, Makridis P, Divanach P. Harvesting Chlorella minutissima using cell coagulants. J Appl Phycol 2010;22:349-55.

[17] Singh J, Gu S. Commercialization potential of microalgae for biofuels production. Renew Sust Energy Rev 2010;14:2596-610.

[18] Spolaore P, Joannis-Cassan C, Duran E, Isambert A. Commercial applications of microalgae. J Biosci Bioeng 2006;101:87-96.

[19] Vandamme D, Foubert I, Muylaert K. Flocculation as a low-cost method for harvesting microalgae for bulk biomass production. Trends Biotechnol 2013;31:233-9.

[20] Dassey AJ, Theegala CS. Harvesting economics and strategies using centrifugation for cost effective separation of microalgae cells for biodiesel applications. Bioresour Technol 2013;128:241-5.

[21] Cai T, Park SY, Li Y. Nutrient recovery from wastewater streams by microalgae: status and prospects. Renew Sust Energy Rev 2013;19:360-9.

[22] Danquah MK, Gladman B, Moheimani N, Forde GM. Microalgal growth characteristics and subsequent influence on dewatering efficiency. Chem Eng $\mathrm{J}$ 2009; 151:73-8.

[23] Molina Grima E, Belarbi EH, Acién Fernández FG, Robles Medina A, Chisti Y. Recovery of microalgal biomass and metabolites: process options and economics. Biotechnol Adv 2003;20:491-515.

[24] Salim S, Bosma R, Vermue MH, Wijffels RH. Harvesting of microalgae by bioflocculation. J Appl Phycol 2011;23:849-55.

[25] Danquah MK, Ang L, Uduman N, Moheimani N, Forde GM. Dewatering of microalgal culture for biodiesel production: exploring polymer flocculation and tangential flow filtration. J Chem Technol Biotechnol 2009;84:1078-83.

[26] Brennan L, Owende P. Biofuels from microalgae - a review of technologies for production, processing, and extractions of biofuels and co-products. Renew Sust Energy Rev 2010;14:557-77.

[27] Uduman N, Qi Y, Danquah MK, Forde GM, Hoadley A. Dewatering of microalgal cultures: a major bottleneck to algae-based fuels. J Renew Sustain Energy 2010;2:012701-15. 
[28] Griffiths MJ, Dicks R, Richardson C, Harrison S. Advantages and challenges of microalgae as a source of oil for biodiesel In: Stoytcheva M, Montero J, editors. Biodiesel - Feedstocks and Processing Technologies, Rijeka: In Tech; 2011. p. 177-92.

[29] Wang B, Li Y, Wu N, Lan C. $\mathrm{CO}_{2}$ bio-mitigation using microalgae. Appl Microbiol Biotechnol 2008;79:707-18.

[30] Schlesinger A, Eisenstadt D, Bar-Gil A, Carmely H, Einbinder S, Gressel J. Inexpensive non-toxic flocculation of microalgae contradicts theories; overcoming a major hurdle to bulk algal production. Biotechnol Adv 2012;30:1023-30.

[31] Show K-Y, Lee D-J. Algal biomass harvesting. In: Pandey A, Lee D-J, Chisti Y, Soccol CR, editors. Biofuels from Algae, Burlington: Elsevier; 2014. p. 85-110.

[32] Mohn FH. Harvesting of micro-algal biomass. Cambridge: Cambridge University Press; 1988.

[33] Habib MAB, Parvin M. A review on culture, production and use of Spirulina as food for humans and feeds for domestic animals and fish. In: Huntington TC, Hasan MR, editors. FAO Fisheries and Aquaculture Circular No1034. Rome: Food and Agriculture Organization of the United Nations; 2008.

[34] Vandamme D, Foubert I, Fraeye I, Meesschaert B, Muylaert K. Flocculation of Chlorella vulgaris induced by high $\mathrm{pH}$ : role of magnesium and calcium and practical implications. Bioresour Technol 2012;105:114-9.

[35] Smith BT, Davis RH. Sedimentation of algae flocculated using naturally-available, magnesium-based flocculants. Algal Res 2012;1:32-9.

[36] Shelef G, Sukenik A, Green M. Microalgae harvesting and processing: a literature review. Haifa (Israel): Technion Research and Development Foundation Ltd; 1984.

[37] Lee AK, Lewis DM, Ashman PJ. Energy requirements and economic analysis of a full-scale microbial flocculation system for microalgal harvesting. Chem Eng Res Des 2010;88:988-96.

[38] Eldridge RJ, Hill DRA, Gladman BR. A comparative study of the coagulation behaviour of marine microalgae. J Appl Phycol 2012;24:1667-79.

[39] Vandamme D, Foubert I, Meesschaert B, Muylaert K. Flocculation of microalgae using cationic starch. J Appl Phycol 2010;22:525-30.

[40] Horiuchi JI, Ohba I, Tada K, Kobayashi M, Kanno T, Kishimoto M. Effective cell harvesting of the halotolerant microalga Dunaliella tertiolecta with $\mathrm{pH}$ control. Journal of Bioscience and Bioengineering 2003;95:412-5. 
[41] Şirin S, Trobajo R, Ibanez C, Salvadó J. Harvesting the microalgae Phaeodactylum tricornutum with polyaluminum chloride, aluminium sulphate, chitosan and alkalinityinduced flocculation. J Appl Phycol 2012;24:1067-80.

[42] Chen F, Liu Z, Li D, Liu C, Zheng P, Chen S. Using ammonia for algae harvesting and as nutrient in subsequent cultures. Bioresour Technol 2012;121:298-303.

[43] Oh H-M, Lee S, Park M-H, Kim H-S, Kim H-C, Yoon J-H, et al. Harvesting of Chlorella vulgaris using a bioflocculant from Paenibacillus sp. AM49. Biotechnol Lett 2001;23:1229-34.

[44] Zhou W, Cheng Y, Li Y, Wan Y, Liu Y, Lin X, et al. Novel fungal pelletizationassisted technology for algae harvesting and wastewater treatment. Appl Biochem Biotechnol 2012;167:214-28.

[45] Wan C, Zhao XQ, Guo SL, Asraful Alam M, Bai FW. Bioflocculant production from Solibacillus silvestris W01 and its application in cost-effective harvest of marine microalga Nannochloropsis oceanica by flocculation. Bioresour Technol 2013;135:20712.

[46] van Den Hende S, Vervaeren H, Desmet S, Boon N. Bioflocculation of microalgae and bacteria combined with flue gas to improve sewage treatment. New Biotechnol 2011;29:23-31.

[47] Lee A, Lewis D, Ashman P. Microbial flocculation, a potentially low-cost harvesting technique for marine microalgae for the production of biodiesel. J Appl Phycol 2009;21:559-67.

[48] Lee J, Cho D-H, Ramanan R, Kim B-H, Oh H-M, Kim H-S. Microalgae-associated bacteria play a key role in the flocculation of Chlorella vulgaris. Bioresour Technol 2013;131:195-201.

[49] van Den Hende S, Vervaeren H, Saveyn H, Maes G, Boon N. Microalgal bacterial floc properties are improved by a balanced inorganic/organic carbon ratio. Biotechnol Bioeng 2011;108:549-58.

[50] Salim S, Vermue MH, Wijffels RH. Ratio between autoflocculating and target microalgae affects the energy-efficient harvesting by bio-flocculation. Bioresour Technol 2012;118:49-55.

[51] Zhou W, Min M, Hu B, Ma X, Liu Y, Wang Q, et al. Filamentous fungi assisted bioflocculation: a novel alternative technique for harvesting heterotrophic and autotrophic microalgal cells. Sep Purif Technol 2013;107:158-65. 
[52] Gultom SO, Hu B. Review of microalgae harvesting via co-pelletization with filamentous fungus. Energies 2013;6:5921-39.

[53] Xie S, Sun S, Dai SY, Yuan JS. Efficient coagulation of microalgae in cultures with filamentous fungi. Algal Research 2013;2:28-33.

[54] Chen CY, Yeh KL, Aisyah R, Lee DJ, Chang JS. Cultivation, photobioreactor design and harvesting of microalgae for biodiesel production: a critical review. Bioresour Technol 2011;102:71-81.

[55] Pragya N, Pandey KK, Sahoo P. A review on harvesting, oil extraction and biofuels production technologies from microalgae. Renew Sust Energy Rev 2013;24:159-71.

[56] Rubio J, Souza ML, Smith RW. Overview of flotation as a wastewater treatment technique. Miner Eng 2002;15:139-55.

[57] Hanotu J, Bandulasena HCH, Zimmerman WB. Microflotation performance for algal separation. Biotechnol Bioeng 2012;109:1663-73.

[58] Liu JC, Chen YM, Ju Y-H. Separation of algal cells from water by column flotation. Sep Sci Technol 1999;34:2259-72.

[59] Ducker WA, Xu Z, Israelachvili JN. Measurements of hydrophobic and DLVO forces in bubble-surface interactions in aqueous solutions. Langmuir 1994;10:3279-89.

[60] Zenouzi A, Ghobadian B, Hejazi M, Rahnemoon P. Harvesting of microalgae Dunaliella salina using electroflocculation. J Agric Sci Technol 2013;15:879-88.

[61] Gao S, Yang J, Tian J, Ma F, Tu G, Du M. Electro-coagulation-flotation process for algae removal. Journal of Hazardous Materials 2010;177:336-43.

[62] Lee AK, Lewis DM, Ashman PJ. Harvesting of marine microalgae by electroflocculation: The energetics, plant design, and economics. Applied Energy 2013;108:45-53.

[63] Rossi N, Derouiniot-Chaplain M, Jaouen P, Legentilhomme P, Petit I. Arthrospira platensis harvesting with membranes: fouling phenomenon with limiting and critical flux. Bioresour Technol 2008;99:6162-7.

[64] Singh M, Shukla R, Das K. Harvesting of microalgal biomass. In: Bux F, editor. Biotechnological Applications of Microalgae (Biodiesel and Value-Added Products), New York: CRC Press; 2013. p. 77-88.

[65] Borowitzka MA, Moheimani NR. Algae for Biofuels and Energy. Dordrecht: Springer; 2012. 
[66] Rossignol N, Vandanjon L, Jaouen P, Quéméneur F. Membrane technology for the continuous separation microalgae/culture medium: compared performances of cross-flow microfiltration and ultrafiltration. Aquac Eng 1999;20:191-208.

[67] Liu D, Wang P, Wei G, Dong W, Hui F. Removal of algal blooms from freshwater by the coagulation-magnetic separation method. Environ Sci Pollut Res Int 2013;20:605.

[68] Farooq W, Lee Y-C, Han J-I, Darpito CH, Choi M, Yang J-W. Efficient microalgae harvesting by organo-building blocks of nanoclays. Green Chemistry 2013;15:749-55.

[69] Rashid N, Rehman MSU, Han J-I. Use of chitosan acid solutions to improve separation efficiency for harvesting of the microalga Chlorella vulgaris. Chem Eng $\mathrm{J}$ 2013;226:238-42.

[70] Xu Y, Purton S, Baganz F. Chitosan flocculation to aid the harvesting of the microalga Chlorella sorokiniana. Bioresour Technol 2013;129:296-301.

[71] Poelman E, De Pauw N, Jeurissen B. Potential of electrolytic flocculation for recovery of micro-algae. Res Cons Recycl 1997;19:1-10.

[72] Cerff M, Morweiser M, Dillschneider R, Michel A, Menzel K, Posten C. Harvesting fresh water and marine algae by magnetic separation: screening of separation parameters and high gradient magnetic filtration. Bioresour Technol 2012;118:289-95.

[73] Bilad MR, Vandamme D, Foubert I, Muylaert K, Vankelecom IF. Harvesting microalgal biomass using submerged microfiltration membranes. Bioresour Technol 2012;111:343-52.

[74] Rios SD, Salvado J, Farriol X, Torras C. Antifouling microfiltration strategies to harvest microalgae for biofuel. Bioresour Technol 2012;119:406-18. 


\section{Figure captions}

Figure 1. Diagram of microalgal harvesting and drying techniques. 


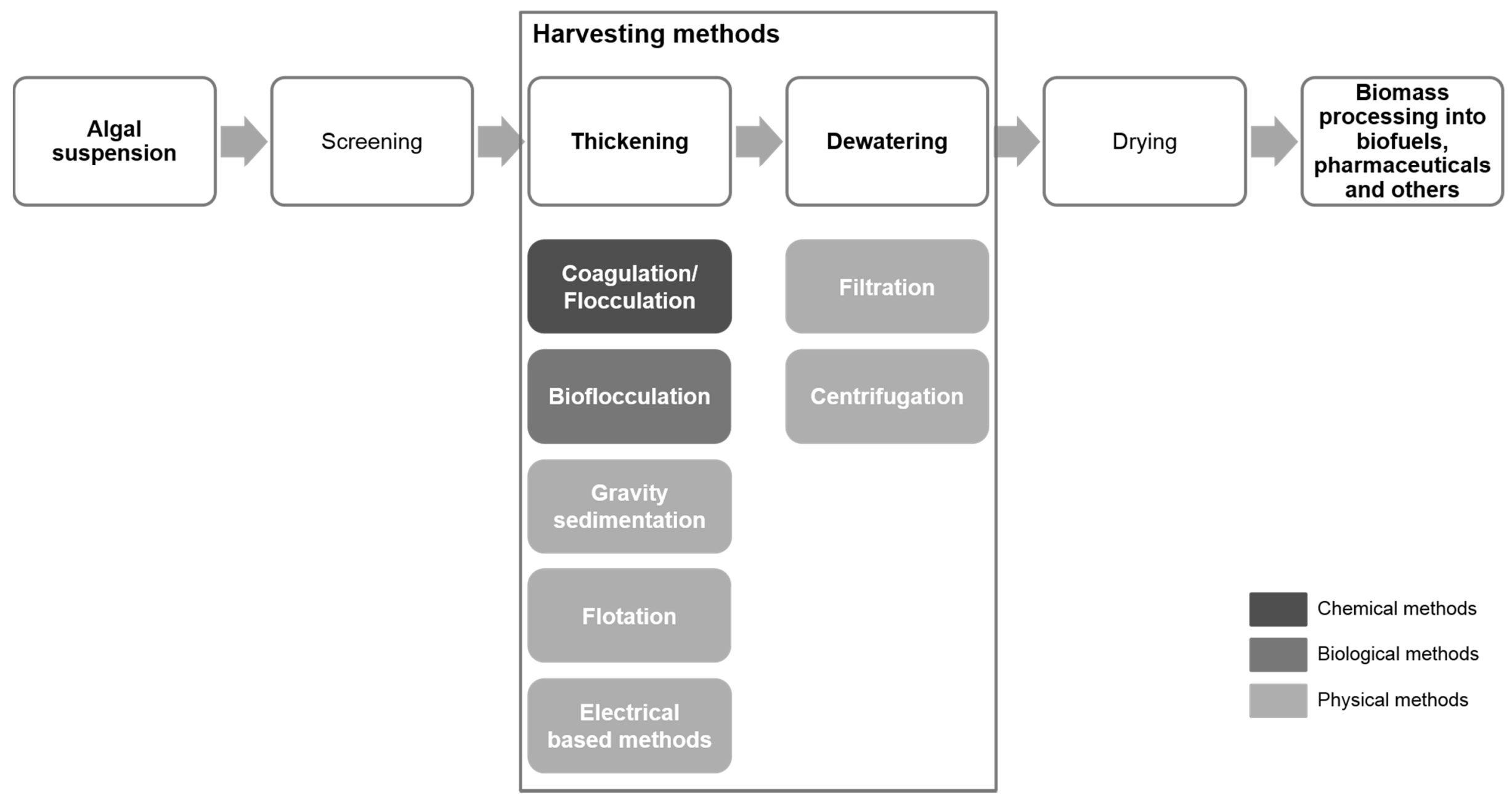

Figure 1. 
Table 1. Advantages and disadvantages of different harvesting methods applied to microalgal biomass

\begin{tabular}{|c|c|c|}
\hline Harvesting method & Advantages & Disadvantages \\
\hline Chemical coagulation/flocculation & $\begin{array}{l}\text { - Simple and fast method; } \\
\text { - No energy requirements. }\end{array}$ & $\begin{array}{l}\text { - Chemical flocculants may be expensive and toxic to } \\
\text { microalgal biomass; } \\
\text { - Recycling of culture medium is limited. }\end{array}$ \\
\hline Auto and bioflocculation & $\begin{array}{l}\text { - Inexpensive method; } \\
\text { - Allows culture medium recycling; } \\
\text { - Non-toxic to microalgal biomass. }\end{array}$ & $\begin{array}{l}\text { - Changes in cellular composition; } \\
\text { - Possibility of microbiological contamination. }\end{array}$ \\
\hline Gravity sedimentation & - Simple and inexpensive method. & $\begin{array}{l}\text { - Time-consuming; } \\
\text { - Possibility of biomass deterioration; } \\
\text { - Low concentration of the algal cake. }\end{array}$ \\
\hline Flotation & $\begin{array}{l}\text { - Feasible for large scale applications; } \\
\text { - Low cost method; } \\
\text { - Low space requirements; } \\
\text { - Short operation times. }\end{array}$ & $\begin{array}{l}\text { - Generally requires the use of chemical flocculants; } \\
\text { - Unfeasible for marine microalgae harvesting. }\end{array}$ \\
\hline Electrical based processes & $\begin{array}{l}\text { - Applicable to a wide variety of microalgal species; } \\
\text { - Do not require the addition of chemical flocculants. }\end{array}$ & $\begin{array}{l}\text { - Poorly disseminated; } \\
\text { - High energetic and equipment costs. }\end{array}$ \\
\hline Centrifugation & $\begin{array}{l}\text { - Fast method; } \\
\text { - High recovery efficiencies; } \\
\text { - Suitable for almost all microalgal species. }\end{array}$ & $\begin{array}{l}\text { - Expensive method; } \\
\text { - High energy requirements; } \\
\text { - Suitable only for the recovery of high-valued products; } \\
\text { - Possibility of cell damage due to high shear forces. }\end{array}$ \\
\hline
\end{tabular}


Table 2. Microalgal biomass recovery by coagulation/flocculation followed by sedimentation.

\begin{tabular}{|c|c|c|c|c|}
\hline Microalgae & Coagulant & Experimental set-up & $\mathbf{R}(\%)$ & Ref. \\
\hline Chlorella vulgaris & $\begin{array}{l}\text { Nano-aminoclays } \\
\text { (Mg-APTES) }\end{array}$ & $\begin{array}{l}\text { CoC: } \mathrm{CM}-\mathrm{F} / 2 \text { medium; } \mathrm{S}=30 \mathrm{~g} \mathrm{~L}^{-1} ; \mathrm{T}=30^{\circ} \mathrm{C} ; \mathrm{V}=500 \mathrm{~mL} ; \mathrm{BC}=1.0 \mathrm{~g}_{\text {dry weight }} \\
\mathrm{L}^{-1} ; \mathrm{CD}=1.0 \mathrm{~g} \mathrm{~L}^{-1} ; \mathrm{pH} 5.0-12.0 ; \mathrm{HP}=30 \mathrm{~min} ; \mathrm{HM}-\text { batch. }\end{array}$ & 99 & [68] \\
\hline Chlorella vulgaris & Chitosan & $\begin{array}{l}\text { CoC: } \mathrm{CM}-\mathrm{BG}-11 ; \mathrm{V}=250 \mathrm{~mL} ; \mathrm{T}=25^{\circ} \mathrm{C} ; \mathrm{pH} 6.0 \text { (adjusted) } \mathrm{CD}=30 \mathrm{mg} \mathrm{L}^{-1} \\
\mathrm{HP}=10 \mathrm{~min} ; \mathrm{HM}-\text { batch. }\end{array}$ & 92 & [69] \\
\hline Chlorella sorokiniana & Chitosan & $\begin{array}{l}\mathrm{CoC}: \mathrm{CM}-\text { modified Tris acetate phosphate medium with } 10 \% \mathrm{NH}_{4} \mathrm{Cl} ; \mathrm{V}=1 \\
\mathrm{~L} ; \mathrm{BC}=0.2-1 \mathrm{~g}_{\text {dry weight }} \mathrm{L}^{-1} ; \mathrm{CD}=10 \mathrm{mg} \mathrm{g}^{-1} \text { microalgal biomass; } \mathrm{pH} 6 ; \mathrm{FC}=200 \mathrm{USD} \\
\text { ton }{ }^{-1} \text { microalgal biomass } ; \mathrm{HM} \text { - batch. }\end{array}$ & 99 & {$[70]$} \\
\hline Chlorella minutissima & $\mathrm{Fe}_{2}\left(\mathrm{SO}_{4}\right)_{3}$ & $\begin{array}{l}\text { CoC: } \mathrm{CM}-\mathrm{f} / 2 \text { medium; } \mathrm{V}=20 \mathrm{~mL} ; \mathrm{BC}=220 \times 10^{6} \text { cells } \mathrm{mL}^{-1} ; \mathrm{CC}=0.75 \mathrm{~g} \mathrm{~L}^{-} \\
{ }^{1} ; \mathrm{HP}=4 \mathrm{~h} ; \mathrm{HM} \text { - batch. }\end{array}$ & 80 & [16] \\
\hline Chlorella minutissima & $\mathrm{AlCl}_{3}$ & $\begin{array}{l}\text { CoC: } \mathrm{CM}-\mathrm{f} / 2 \text { medium; } \mathrm{V}=20 \mathrm{~mL} ; \mathrm{BC}=220 \times 10^{6} \text { cells } \mathrm{mL}^{-1} ; \mathrm{CC}=0.5 \mathrm{~g} \mathrm{~L}^{-1} \\
\mathrm{HP}=1 \mathrm{~h} ; \mathrm{HM} \text { - batch. }\end{array}$ & 80 & [16] \\
\hline Phaeodactylum tricornutum & $\begin{array}{l}\text { PAC } \\
\text { (polyaluminium } \\
\text { chloride) }\end{array}$ & $\begin{array}{l}\text { CoC: } \mathrm{CM} \text { - filtered and sterilized seawater with commercial fertilizer, } \mathrm{B} \text { group } \\
\text { vitamins and sodium silicate; } \mathrm{V}=250 \mathrm{~mL} ; \mathrm{BC}=104.62 \mathrm{mg}_{\text {dry weight }} \mathrm{L}^{-1} ; \mathrm{CD}= \\
0.27 \mathrm{~kg} \mathrm{~kg}^{-1} \text { microalgal biomass; } \mathrm{pH} 7.5 ; \mathrm{FC}=0.429-1,429 \mathrm{USD} \mathrm{kg}^{-1} \text { coagulant } ; \mathrm{HM}- \\
\text { batch. }\end{array}$ & 67 & [41] \\
\hline Phaeodactylum tricornutum & $\mathrm{Al}_{2}\left(\mathrm{SO}_{4}\right)_{3}$ & $\begin{array}{l}\mathrm{CoC}: \mathrm{CM} \text { - filtered and sterilized seawater with commercial fertilizer, } \mathrm{B} \text { group } \\
\text { vitamins and sodium silicate; } \mathrm{V}=250 \mathrm{~mL} ; \mathrm{BC}=104.62 \mathrm{mg}_{\text {dry weight }} \mathrm{L}^{-1} ; \mathrm{CD}= \\
0.27 \mathrm{~kg} \mathrm{~kg}^{-1} \text { microalgal biomass; } \mathrm{pH} 5.9 ; \mathrm{FC}=0.976-2.073 \mathrm{USD} \mathrm{kg}^{-1} \text { coagulant } ; \mathrm{HM}- \\
\text { batch. }\end{array}$ & 83 & [41] \\
\hline Phaeodactylum tricornutum & Chitosan & $\begin{array}{l}\text { CoC: } \mathrm{CM} \text { - filtered and sterilized seawater with commercial fertilizer, B group } \\
\text { vitamins and sodium silicate; } \mathrm{V}=250 \mathrm{~mL} ; \mathrm{BC}=104.62 \mathrm{mg}_{\text {dry weight }} \mathrm{L}^{-1} ; \mathrm{CD}= \\
0.18 \mathrm{~kg} \mathrm{~kg}^{-1} \text { microalgal biomass; } \mathrm{pH} 9.9 \text { (adjusted); } \mathrm{FC}=2-100 \mathrm{USD} \mathrm{kg}{ }^{-1} \text { coagulant } ; \mathrm{HM} \text { - } \\
\text { batch. }\end{array}$ & 91,8 & {$[41]$} \\
\hline Dunaliella salina & $\begin{array}{l}\text { Electrolytic } \\
\text { flocculation; }\end{array}$ & CoC: $\mathrm{n} / \mathrm{a} ; \mathrm{CD}=50 \mathrm{~A} \mathrm{~m}^{-2} ; \mathrm{HP}=7 \mathrm{~min} ; \mathrm{EC}=0.23 \mathrm{kWh} \mathrm{m}^{-3}$ & 98.9 & {$[60]$} \\
\hline
\end{tabular}


Coelosphaerium sp., Aphanizomenon sp.,

Closterium sp., , Pediastrum sp., Cryptomonas

sp., Staurastrum sp., Asterionella sp., Cyclotell sp. and Melosira sp.

Tetraselmins sp.

Tetraselmins sp.
Electrolytic

flocculation

6 cathodes and 3 anodes $26.3 \mathrm{~cm}$ apart; Voltage $=26.5 \mathrm{~V} ; \mathrm{CI}=1.0 \mathrm{~A} ; \mathrm{BC}=1$

$50 \mathrm{mg}_{\text {dry weight }} \mathrm{L}^{-1} ; \mathrm{HP}=75 \mathrm{~min} ; \mathrm{HM}$ - batch; $\mathrm{EC}=0.331 \mathrm{kWh} \mathrm{m}^{-3}$.

96.3

CoC: $\mathrm{CM}$ - f $/ 2$ medium; $\mathrm{T}=22^{\circ} \mathrm{C} ; \mathrm{S}=1 \mathrm{M} ; \mathrm{pH} 8.4$ (adjusted); $\mathrm{C}_{\mathrm{i}}=0.25 \mathrm{~kg}_{\text {dry }}$

Electro-flocculation

weight $\mathrm{m}^{-3} ; \mathrm{V}=1$ $0.559 \mathrm{MJ} \mathrm{m}^{-3}$

Electro-flocculation $\quad \mathrm{CoC}: \mathrm{CM}-\mathrm{f} / 2$ medium; $\mathrm{T}=22^{\circ} \mathrm{C} ; \mathrm{S}=1 \mathrm{M} ; \mathrm{pH} 8.4$ (adjusted); $\mathrm{C}_{\mathrm{i}}=0.25 \mathrm{~kg}_{\text {dry }}$ followed by gravity $\quad$ weight $\mathrm{m}^{-3} ; \mathrm{V}=150 \mathrm{~mL} ;$ Voltage $=10 \mathrm{~V}, \mathrm{CI}=5 \mathrm{~A} ; \mathrm{SS}=7.5 \mathrm{rad} \mathrm{s}^{-1} ; \mathrm{HP}=45.5$ sedimentation $\min ; \mathrm{EC}=0.328 \mathrm{MJ} \mathrm{m}^{-3}$

BC - initial biomass concentration, $\mathrm{CC}$ - coagulant concentration, $\mathrm{CD}$ - coagulant dose, $\mathrm{CI}$ - current intensity, $\mathrm{CM}$ - culture medium, CoC - conditions of culturing, EC - energy consumption, $\mathrm{FC}$ - Flocculation cost, $\mathrm{HM}$ - harvesting mode, $\mathrm{HP}$ - harvesting period, $\mathrm{R}-$ recovery efficiency, $R=C_{i}-C_{f} / C i \times 100 \%$, where $\mathrm{C}_{\mathrm{i}}$ and $\mathrm{C}_{\mathrm{f}}$ are the initial and final microalgal concentrations, respectively, $\mathrm{S}$ - salinity, SS - stirring speed, T - temperature, V - volume. 
Table 3. Microalgal biomass recovery by autoflocculation followed by sedimentation

\begin{tabular}{|c|c|c|c|c|}
\hline Microalgae & Procedure & Experimental set-up & $\mathbf{R}(\%)$ & Ref. \\
\hline Chlorella vulgaris & $\begin{array}{l}\mathrm{pH} \text { adjustment, } \\
\mathrm{NaOH}\end{array}$ & $\begin{array}{l}\text { CoC: } \mathrm{CM} \text { - dechlorinated tap water enriched with inorganic nutrients, with } \\
\text { aeration; } \mathrm{V}=30 \mathrm{~L} ; \mathrm{BC}=0.5 \mathrm{~g}_{\text {dry weight }} \mathrm{L}^{-1} ; \mathrm{CD}=9 \mathrm{mg} \mathrm{g}^{-1} \text { microalgal biomass; } \mathrm{pH} 10.8 \text {; } \\
\mathrm{HM} \text { - batch. }\end{array}$ & 98 & [34] \\
\hline Chlorella vulgaris & $\begin{array}{l}\mathrm{pH} \text { adjustment, } \\
\mathrm{KOH}\end{array}$ & $\begin{array}{l}\text { CoC: } \mathrm{CM} \text { - dechlorinated tap water enriched with inorganic nutrients, with } \\
\text { aeration; } \mathrm{V}=30 \mathrm{~L} ; \mathrm{BC}=0.5 \mathrm{~g}_{\text {dry weight }} \mathrm{L}^{-1} ; \mathrm{CD}=12 \mathrm{mg} \mathrm{g}^{-1} \text { microalgal biomass; } \mathrm{pH} 10.8 \text {; } \\
\mathrm{HM} \text { - batch. }\end{array}$ & 98 & [34] \\
\hline Chlorella vulgaris & $\begin{array}{l}\mathrm{pH} \text { adjustment, } \\
\mathrm{Ca}(\mathrm{OH})_{2}\end{array}$ & $\begin{array}{l}\text { CoC: } \mathrm{CM} \text { - dechlorinated tap water enriched with inorganic nutrients, with } \\
\text { aeration; } \mathrm{V}=30 \mathrm{~L} ; \mathrm{BC}=0.5 \mathrm{~g}_{\text {dry weight }} \mathrm{L}^{-1} ; \mathrm{CD}=18 \mathrm{mg} \mathrm{g}^{-1} \text { microalgal biomass; } \mathrm{pH} \mathrm{10.8;} \\
\mathrm{HM} \text { - batch. }\end{array}$ & 98 & [34] \\
\hline Chlorella vulgaris & $\begin{array}{l}\mathrm{pH} \text { adjustment, } \\
\mathrm{Mg}(\mathrm{OH})_{2}\end{array}$ & $\begin{array}{l}\text { CoC: } \mathrm{CM} \text { - dechlorinated tap water enriched with inorganic nutrients, with } \\
\text { aeration; } \mathrm{V}=30 \mathrm{~L} ; \mathrm{BC}=0.5 \mathrm{~g}_{\text {dry weight }} \mathrm{L}^{-1} ; \mathrm{CD}=27 \mathrm{mg} \mathrm{g}^{-1} \text { microalgal biomass; } \mathrm{pH} 9.7 \text {; } \\
\mathrm{FC}=18 \mathrm{USD} \text { ton }^{-1} \text { microalgal biomass } ; \mathrm{HM} \text { - batch. }\end{array}$ & 98 & [34] \\
\hline Chlorella vulgaris & None & $\begin{array}{l}\text { CoC: } \mathrm{CM} \text { - marine medium from Salim et al [24]; } \mathrm{SS}=100 \mathrm{rpm} ; 2 \% \mathrm{CO}_{2} \\
\text { enriched airflow; light:dark cycle of } 16: 8 \mathrm{~h} ; \mathrm{LI}=50 \mu \mathrm{mol} \mathrm{m}^{-2} \mathrm{~s}^{-1} ; \mathrm{V}=100 \mathrm{~mL} \text {; } \\
\mathrm{T}=25^{\circ} \mathrm{C} ; \mathrm{HP}=3 \mathrm{~h} ; \mathrm{HM} \text { - batch. }\end{array}$ & 25 & {$[50]$} \\
\hline Neochloris oleoabundans & None & $\begin{array}{l}\text { CoC: } \mathrm{CM} \text { - marine medium from Salim et al. [24]; } \mathrm{SS}=100 \mathrm{rpm} ; 2 \% \mathrm{CO}_{2} \\
\text { enriched airflow; light:dark cycle of } 16: 8 \mathrm{~h} ; \mathrm{LI}=50 \mu \mathrm{mol} \mathrm{m}^{-2} \mathrm{~s}^{-1} ; \mathrm{V}=100 \mathrm{~mL} \text {; } \\
\mathrm{T}=25^{\circ} \mathrm{C} ; \mathrm{HP}=3 \mathrm{~h} ; \mathrm{HM} \text { - batch. }\end{array}$ & 40 & {$[50]$} \\
\hline
\end{tabular}

$\mathrm{BC}$ - initial biomass concentration, CC - coagulant concentration, $\mathrm{CD}$ - coagulant dose, $\mathrm{CI}$ - current intensity, CM - culture medium, CoC - conditions of culturing, HM - harvesting mode, HP - harvesting period, LI - light intensity, $\mathrm{R}$ - recovery efficiency, $R=C_{i}-C_{f} / C i \times 100 \%$, where $\mathrm{C}_{\mathrm{i}}$ and $\mathrm{C}_{\mathrm{f}}$ are the initial and final microalgal concentrations, respectively, $\mathrm{SS}-$ stirring speed, $\mathrm{T}$

- temperature, $\mathrm{V}$ - volume. 
Table 4. Microalgal biomass recovery by bioflocculation followed by sedimentation

\begin{tabular}{|c|c|c|c|c|}
\hline Microalgae & Microorganism & Experimental set-up & $\mathbf{R}(\%)$ & Ref. \\
\hline Chlorella vulgaris & Paenibacillus sp. & $\begin{array}{l}\text { CoC: } \mathrm{CM} \text { - modified Chu } 13 \text { medium; } \mathrm{V}=50 \mathrm{~mL} . \mathrm{BC}-\text { use of diluted } \\
\text { Paenibacillus sp. broth as flocculating agent; } \mathrm{pH} 5-11 \text { (adjusted); } \\
\mathrm{CC}\left(\mathrm{CaCl}_{2}\right)=6.8 \mathrm{mM} ; \mathrm{HM} \text { - batch. }\end{array}$ & 93 & [43] \\
\hline $\begin{array}{l}\text { Botryococcus braunii, } \\
\text { Scenedesmus quadricauda and } \\
\text { Selenastrum capricornutum }\end{array}$ & Paenibacillus sp. & $\begin{array}{l}\mathrm{CoC} \text { : } \mathrm{CM} \text { - modified Chu } 13 \text { medium; } \mathrm{V}=50 \mathrm{~mL} ; \mathrm{BC}-\text { use of diluted } \\
\text { Paenibacillus sp. broth as flocculating agent; pH 5-11 (adjusted); } \\
\mathrm{CC}\left(\mathrm{CaCl}_{2}\right)=6.8 \mathrm{mM} ; \mathrm{HM} \text { - batch. }\end{array}$ & $91-95$ & [43] \\
\hline $\begin{array}{l}\text { Anabaena } \\
\text { flos-aquae and Microcystis } \\
\text { aeruginosa }\end{array}$ & Paenibacillus sp. & $\begin{array}{l}\text { CoC: } \mathrm{CM} \text { - modified Chu } 13 \text { medium; } \mathrm{V}=50 \mathrm{~mL} ; \mathrm{BC}-\text { use of diluted } \\
\text { Paenibacillus sp. broth as flocculating agent; } \mathrm{pH} 5-11 \text { (adjusted); } \\
\mathrm{CC}\left(\mathrm{CaCl}_{2}\right)=6.8 \mathrm{mM} ; \mathrm{HM} \text { - batch. }\end{array}$ & $38-49$ & [43] \\
\hline Nannochloropsis oceanica & Solibacillus silvestris & $\begin{array}{l}\mathrm{CoC}: \mathrm{CM}-\mathrm{f} / 2 \text { medium; } \mathrm{V}=200 \mathrm{~mL} ; \text { Purified bioflocculant from } \\
\text { Solibacillus silvestris growth media was used at the concentration of } 0.1 \% \\
(\mathrm{w} / \mathrm{v}) ; \mathrm{pH} 8.7 ; \mathrm{T}=25^{\circ} \mathrm{C} ; \mathrm{HM} \text { - batch. }\end{array}$ & 88 & [45] \\
\hline Pleurochrysis carterae & Tap water bacterial inoculum & $\begin{array}{l}\mathrm{CoC} \text { : } \mathrm{CM} \text { - modified } \mathrm{BG}-11 \text { medium, } 0.5 \mathrm{~g} \mathrm{~L}^{-1} \text { substrate (acetate, glycerine } \\
\text { or glucose) with mixing; } \mathrm{V}=100 \mathrm{~mL} \text {; no illumination; } 0.09 \%(\mathrm{v} / \mathrm{v}) \text { of the } \\
\text { microbial culture is used as flocculating agent; } \mathrm{HP}=30 \mathrm{~min} ; \mathrm{HM} \text { - batch. }\end{array}$ & $\begin{array}{c}90-93 \\
(\mathrm{CF}=100-131)\end{array}$ & [47] \\
\hline $\begin{array}{l}\text { Chlorella sp., Pediastrum sp., } \\
\text { Phormidium } \mathrm{sp} . \text { and } \\
\text { Scenedesmus } \mathrm{sp} . \text { consortium }\end{array}$ & $\begin{array}{l}\text { Aerobic activated slugde bacterial } \\
\text { inoculum from a municipal } \\
\text { wastewater treatment plant }\end{array}$ & $\begin{array}{l}\text { CoC: co-cultivation in synthetic wastewater; light:dark cycle of } 15: 9 \mathrm{~h} ; \mathrm{LI} \\
=100 \mu \mathrm{mol} \mathrm{m} \mathrm{m}^{-2} ; \mathrm{V}=1.5 \mathrm{~L} ; \mathrm{T}=23-29^{\circ} \mathrm{C} ; \mathrm{HP}=1.5 \mathrm{~h} ; \mathrm{HM}-\text { batch. }\end{array}$ & $\begin{array}{c}98 \\
\left(23.2 \mathrm{~g} \mathrm{TSS} \mathrm{L}^{-1}\right)\end{array}$ & [46] \\
\hline Chlorella vulgaris & Ettlia texensis & $\begin{array}{l}\text { CoC: co-cultivation; } \mathrm{CM} \text { - marine medium from Salim et al. [24]; } \mathrm{SS}=100 \\
\mathrm{rpm} ; 2 \% \mathrm{CO}_{2} \text { enriched airflow; light:dark cycle of } 16: 8 \mathrm{~h} ; \mathrm{LI}=50 \mu \mathrm{mol} \mathrm{m} \\
{ }^{2} \mathrm{~s}^{-1} ; \mathrm{V}=100 \mathrm{~mL} ; \mathrm{T}=25^{\circ} \mathrm{C} ; \mathrm{HP}=3 \mathrm{~h} ; \mathrm{R}_{\mathrm{fnf}}=1 ; \mathrm{HM}-\text { batch. }\end{array}$ & 55 & [50] \\
\hline Chlorella vulgaris & Scenedesmus obliquus & $\begin{array}{l}\text { CoC: co-cultivation; } \mathrm{CM} \text { - marine medium from Salim et al. [24]; } \mathrm{SS}=100 \\
\mathrm{rpm} ; 2 \% \mathrm{CO}_{2} \text { enriched airflow; light:dark cycle of } 16: 8 \mathrm{~h} ; \mathrm{LI}=50 \mu \mathrm{mol} \mathrm{m} \\
{ }^{2} \mathrm{~s}^{-1} ; \mathrm{V}=100 \mathrm{~mL} ; \mathrm{T}=25^{\circ} \mathrm{C} ; \mathrm{HP}=3 \mathrm{~h} ; \mathrm{R}_{\mathrm{fnf}}=1 ; \mathrm{HM}-\text { batch. }\end{array}$ & 34 & {$[50]$} \\
\hline
\end{tabular}


Ankistrodesmus falcatus

Neochloris oleoabundans

Chlorella vulgaris

Chlorella vulgaris

Chlorella vulgaris

Chlorella vulgaris
Tetraselmis suecica

Aspergillus oryzae

Aspergillus oryzae

Cunninghamella echinulata
Aspergillus oryzae
CoC: co-cultivation; $\mathrm{CM}$ - marine medium from Salim et al. [24]; $\mathrm{SS}=100$ rpm; $2 \% \mathrm{CO}_{2}$ enriched airflow; light:dark cycle of $16: 8 \mathrm{~h} ; \mathrm{LI}=50 \mu \mathrm{mol} \mathrm{m}$ ${ }^{2} \mathrm{~s}^{-1} ; \mathrm{V}=100 \mathrm{~mL} ; \mathrm{T}=25^{\circ} \mathrm{C} ; \mathrm{HP}=3 \mathrm{~h} ; \mathrm{R}_{\mathrm{fnf}}=1 ; \mathrm{HM}-$ batch.

CoC: co-cultivation, $\mathrm{CM}$ - marine medium from Salim et al. [24]; $\mathrm{SS}=100$ $\mathrm{rpm}, 2 \% \mathrm{CO}_{2}$ enriched airflow, light:dark cycle of $16: 8 \mathrm{~h}, \mathrm{LI}=50 \mu \mathrm{mol} \mathrm{m}$

$\mathrm{s}^{-1}, \mathrm{~V}=100 \mathrm{~mL}, \mathrm{~T}=25^{\circ} \mathrm{C} ; \mathrm{HP}=3 \mathrm{~h}, \mathrm{R}_{\mathrm{fnf}}=0.74 ; \mathrm{HM}$ : batch.

$\mathrm{L}^{-1}$; glucose; under dark; $\mathrm{T}=25^{\circ} \mathrm{C} ; \mathrm{SC}=1.1 \times 10^{4}$ spores $\mathrm{mL}^{-1} ; \mathrm{pH} 4.5-7.0$ (adjusted); $\mathrm{HP}=3 \mathrm{~d} ; \mathrm{HM}$ - batch.

CoC: co-cultivation, autotrophic; CM - supplemented BG-11; light:dark cycle of 24:0 h; $\mathrm{LI}=120 \mu \mathrm{mol} \mathrm{m}^{-2} \mathrm{~s}^{-1} ; \mathrm{T}=25^{\circ} \mathrm{C} ; \mathrm{SC}=1.1 \times 10^{4}$ spores $\mathrm{mL}$ ${ }^{1}$; pH 4.0-5.0 (adjusted); $\mathrm{CS}=10 \mathrm{~g} \mathrm{~L}^{-1}$ glucose (later added); $\mathrm{HP}=2 \mathrm{~d}$; HM - batch.

CoC: co-cultivation, autotrophic; CM - supplemented BG-11; light:dark cycle of $24: 0 \mathrm{~h} ; \mathrm{LI}=120 \mu \mathrm{mol} \mathrm{m}{ }^{-2} \mathrm{~s}^{-1} ; \mathrm{T}=25^{\circ} \mathrm{C} ; \mathrm{SC}=1.1 \times 10^{4}$ spores $\mathrm{mL}$ '; $\mathrm{pH}$ 4.0-5.0 (adjusted); HP = $3 \mathrm{~d}$; HM - batch.

CoC: co-cultivation; $\mathrm{T}=25^{\circ} \mathrm{C} ; \mathrm{SS}=120 \mathrm{rpm}$; light:dark cycle of $24: 0 \mathrm{~h}$; $\mathrm{R}_{\mathrm{fm}}=1: 2 ; \mathrm{SC}=3.44 \times 10^{7}$ spores $\mathrm{L}^{-1}$.

$\mathrm{BC}$ - initial biomass concentration, $\mathrm{CC}$ - coagulant concentration, $\mathrm{CoC}$ - conditions of culturing, CS - carbon source, CF - concentration factor, HP - harvesting period, LI - light intensity, R recovery efficiency, $R=C_{i}-C_{f} / C i \times 100 \%$, where $\mathrm{C}_{\mathrm{i}}$ and $\mathrm{C}_{\mathrm{f}}$ are the initial and final microalgal concentrations, respectively, $\mathrm{R}$ fnf - ratio of flocculating/non-flocculating microalgae, $\mathrm{SC}-\mathrm{spore}$ concentration, $\mathrm{SS}$ - stirring speed, T - temperature, TSS - total suspended solids, V - volume. 
Table 5. Microalgal biomass recovery by flotation

\begin{tabular}{|c|c|c|c|c|}
\hline Microalgae & Process & Experimental set-up & $\mathbf{R}(\%)$ & Ref. \\
\hline Chlorella sp. & Flotation & $\begin{array}{l}\text { CoC: } \mathrm{NC} \text { medium; } \mathrm{T}=25^{\circ} \mathrm{C} ; \mathrm{SS}=75 \mathrm{rpm} ; \mathrm{V}=200 \mathrm{~mL} ; \mathrm{pH} 8 ; \mathrm{AFR}=114 \mathrm{~mL} \mathrm{~min}^{-1} ; \mathrm{BC} \\
=6.8 \times 10^{5} \text { cells } \mathrm{mL}^{-1} ; \text { addition of chitosan }\left(10 \mathrm{mg} \mathrm{L}^{-1}\right) \text { and } \mathrm{SDS}\left(20 \mathrm{mg} \mathrm{L}^{-1}\right) .\end{array}$ & 90 & [58] \\
\hline Dunaliella salina & $\begin{array}{l}\text { Microflotation preceded by } \\
\text { flocculation }\end{array}$ & $\begin{array}{l}\text { CoC: D. salina growth medium; V }=2 \mathrm{~L} ; \mathrm{T}=20{ }^{\circ} \mathrm{C} \text {; microflotation preceded by } \\
\text { flocculation with } 150 \mathrm{mg} \mathrm{L}^{-1} \mathrm{FeCl}_{3} ; \mathrm{pH} 5, \mathrm{DD}=26 \mathrm{~cm} .\end{array}$ & 98.2 & [57] \\
\hline $\begin{array}{l}\text { Microcystis } \\
\text { aeruginosa }\end{array}$ & Electro-coagulation-flotation & $\begin{array}{l}\text { CoC: } \mathrm{n} / \mathrm{a} ; \mathrm{T}=\text { room temperature; } \mathrm{pH} 7 ; \mathrm{V}=1 \mathrm{~L} ; \mathrm{SS}=200 \mathrm{rpm} ; \mathrm{C}_{\mathrm{i}}=1.2 \times 10^{9}-1.4 \times 10^{9} \\
\text { cells } \mathrm{L}^{-1} ; \mathrm{HP}=45 \mathrm{~min} ; \text { aluminum electrode. }\end{array}$ & 100 & {$[61]$} \\
\hline $\begin{array}{l}\text { Microcystis } \\
\text { aeruginosa }\end{array}$ & Electro-coagulation-flotation & $\begin{array}{l}\mathrm{T}=\text { room temperature; } \mathrm{pH} 7 ; \mathrm{V}=1 \mathrm{~L} ; \mathrm{SS}=200 \mathrm{rpm} ; \mathrm{C}_{\mathrm{i}}=1.2 \times 10^{9}-1.4 \times 10^{9} \text { cells } \mathrm{L}^{-1} ; \mathrm{CD} \\
=1 \mathrm{~mA} \mathrm{~cm} \\
\end{array}$ & 78.9 & {$[61]$} \\
\hline $\begin{array}{l}\text { Microcystis } \\
\text { aeruginosa }\end{array}$ & Electro-coagulation-flotation & $\begin{array}{l}\mathrm{T}=\text { room temperature; } \mathrm{pH} 7 ; \mathrm{V}=1 \mathrm{~L} ; \mathrm{SS}=200 \mathrm{rpm} ; \mathrm{C}_{\mathrm{i}}=1.2 \times 10^{9}-1.4 \times 10^{9} \text { cells } \mathrm{L}^{-1} ; \mathrm{CD} \\
=0.5 \mathrm{~mA} \mathrm{~cm}-2 ; \mathrm{HP}=25 \mathrm{~min} \text { aluminum electrode } ; \mathrm{EC}=0.20 \mathrm{kWh} \mathrm{m}^{-3} .\end{array}$ & 45 & [61] \\
\hline $\begin{array}{l}\text { Microcystis } \\
\text { aeruginosa }\end{array}$ & Electro-coagulation-flotation & $\begin{array}{l}\mathrm{T}=\text { room temperature; } \mathrm{pH} 7 ; \mathrm{V}=1 \mathrm{~L} ; \mathrm{SS}=200 \mathrm{rpm} ; \mathrm{C}_{\mathrm{i}}=1.2 \times 10^{9}-1.4 \times 10^{9} \text { cells } \mathrm{L}^{-1} ; \mathrm{CD} \\
=5.0 \mathrm{~mA} \mathrm{~cm}-2 ; \mathrm{HP}=25 \mathrm{~min} \text { aluminum electrode } ; \mathrm{EC}=2.28 \mathrm{kWh} \mathrm{m}^{-3} .\end{array}$ & 100 & {$[61]$} \\
\hline
\end{tabular}


Table 6. Microalgal biomass recovery by filtration

\begin{tabular}{|c|c|c|c|c|}
\hline Microalgae & Process & Experimental set-up & $\begin{array}{l}\text { Resulting TSS } \\
(\%)\end{array}$ & Ref. \\
\hline Coelastrum proboscideum & $\begin{array}{l}\text { Pressure filtration; } \\
\text { Netzsch chamber filter }\end{array}$ & $\mathrm{HM}$ - batch; one step; $\mathrm{EC}=0.88 \mathrm{kWh} \mathrm{m}^{-3}$. & $22-27(\mathrm{CF}=245)$ & {$[23]$} \\
\hline Coelastrum proboscideum & $\begin{array}{l}\text { Pressure filtration; } \\
\text { Cylindrical sieve } \\
\text { rotator; Englesmann }\end{array}$ & $\mathrm{HM}$ - continuous; one step; $\mathrm{EC}=0.3 \mathrm{kWh} \mathrm{m}^{-3}$. & $7.5(\mathrm{CF}=75)$ & {$[23]$} \\
\hline Coelastrum proboscideum & $\begin{array}{l}\text { Vacuum filtration; } \\
\text { Non-precoat vacuum } \\
\text { drum filter }\end{array}$ & $\mathrm{HM}$ - continuous; one step; $\mathrm{EC}=5.9 \mathrm{kWh} \mathrm{m}^{-3}$. & $18(\mathrm{CF}=180)$ & {$[23]$} \\
\hline Coelastrum proboscideum & $\begin{array}{l}\text { Vacuum filtration; } \\
\text { Suction filter }\end{array}$ & $\mathrm{HM}$ - batch; one step; $\mathrm{EC}=0.1 \mathrm{kWh} \mathrm{m}^{-3}$. & $8(\mathrm{CF}=80)$ & {$[23]$} \\
\hline Chlorella vulgaris & Magnetic filtration & $\begin{array}{l}\text { CoC: } \mathrm{CM} \text { - modified TAP-medium (no TRIS, no acetate) } \mathrm{C}_{\text {salt }, 0}=0.7-3.1 \mathrm{~g} \mathrm{~L}^{-1} \text {; } \\
\mathrm{V}=5 \mathrm{~mL} ; \mathrm{pH} 8 \text { (adjusted); MagSilica seeding } \mathrm{m}_{\mathrm{mp}} / \mathrm{m}_{\mathrm{X}, 0}=1 ; \mathrm{HP}=30 \mathrm{~min} ; \mathrm{HM} \\
\text { - continuous. }\end{array}$ & 90 & {$[72]$} \\
\hline Chlorella vulgaris & $\begin{array}{l}\text { Submerged } \\
\text { microfiltration; } \\
\text { Membrane PVDF-9 }\end{array}$ & $\begin{array}{l}\text { CoC: } \mathrm{CM}-\mathrm{WC} \text { medium; } \mathrm{pH} 8.5 \text { (adjusted); } \mathrm{BC}=0.41 \mathrm{~g}_{\text {dry weight }} \mathrm{L}^{-1} ; \mathrm{EC}=0.27 \\
\mathrm{kWh} \mathrm{m}{ }^{-3} \text {. }\end{array}$ & 98 & {$[73]$} \\
\hline Phaeodactylum tricornutum & $\begin{array}{l}\text { Submerged } \\
\text { microfiltration; } \\
\text { membrane PVDF-9 }\end{array}$ & $\begin{array}{l}\text { CoC: } \mathrm{CM} \text { : WC medium supplemented with synthetic seawater; } \mathrm{pH} 8.5 \\
\text { (adjusted); } \mathrm{BC}=0.23 \mathrm{~g}_{\text {dry weight }} \mathrm{L}^{-1} ; \mathrm{EC}=0.25 \mathrm{~kW} \mathrm{~h} \mathrm{~m}^{-3} \text {. }\end{array}$ & 70 & {$[73]$} \\
\hline Phaeodactylum tricornutum & Ultrafiltration & $\begin{array}{l}\text { CoC: } \mathrm{CM}-\mathrm{f} / 2 \text { medium; } \mathrm{BC}=3.7 \times 10^{6} \text { cells } \mathrm{L}^{-1} ; \mathrm{V}=900 \mathrm{~L} ; \mathrm{HP}=1 \mathrm{~h} ; \mathrm{EC}= \\
0.75 \mathrm{USD} \mathrm{kg}^{-1} \text { biomass. }\end{array}$ & $\mathrm{CF}=10$ & {$[74]$} \\
\hline
\end{tabular}

$\mathrm{BC}$ - initial biomass concentration, $\mathrm{CF}$ - concentration factor, CM - culture medium CoC - Conditions of culturing, $\mathrm{C}_{\mathrm{salt}, 0}-$ initial salt concentration, EC - energy consumption/cost, HM harvesting mode, $\mathrm{HP}=$ harvesting period, $\mathrm{m}_{\mathrm{mp}} / \mathrm{m}_{\mathrm{X}, 0}-$ ratio between mass of magnetic particles and biomass at initial time, $\mathrm{V}-$ volume, TSS - total suspended solids. 
Table 7. Microalgal biomass recovery by centrifugation

\begin{tabular}{|c|c|c|c|c|}
\hline Microalgae & Equipment & Experimental set-up & $\begin{array}{l}\text { Resulting TSS } \\
(\%)\end{array}$ & Ref. \\
\hline $\begin{array}{l}\text { Scenedesmus sp. and Coelastrum } \\
\text { proboscideum }\end{array}$ & $\begin{array}{l}\text { Self-cleaning, disk-stack centrifuge; } \\
\text { Westfalia }\end{array}$ & CoC: $\mathrm{n} / \mathrm{a} ; \mathrm{HM}$ : continuous; one-step; $\mathrm{EC}=1 \mathrm{kWh} \mathrm{m}^{-3}$. & $12(\mathrm{CF}=120)$ & {$[23]$} \\
\hline $\begin{array}{l}\text { Scenedesmus sp. and Coelastrum } \\
\text { proboscideum }\end{array}$ & Nozzle discharge centrifuge; Westalia & CoC: $\mathrm{n} / \mathrm{a} ; \mathrm{HM}$ : continuous; $\mathrm{EC}=0.72 \mathrm{kWh} \mathrm{m}^{-3}$. & $\begin{array}{l}2-15(\mathrm{CF}=20- \\
150)\end{array}$ & [23] \\
\hline Nannochloropsis sp. & $\begin{array}{l}\text { 1.5-HP }(1.12 \mathrm{~kW}) \text { continuous-flow } \\
\text { centrifuge; US Filter-Maxx }\end{array}$ & $\begin{array}{l}\text { CoC: } \mathrm{CM}-\mathrm{f} / 2 \text { medium; } \mathrm{BC}=100 \mathrm{mg}_{\text {dry weight }} \mathrm{L}^{-1} ; \mathrm{HM}- \\
\text { continuous; } \mathrm{EC}=20 \mathrm{kWh} \mathrm{m} \mathrm{m}^{-3} \text {. }\end{array}$ & 96 & {$[20]$} \\
\hline Nannochloropsis sp. & $\begin{array}{l}\text { 1.5-HP }(1.12 \mathrm{~kW}) \text { continuous-flow } \\
\text { centrifuge; US Filter-Maxx }\end{array}$ & $\begin{array}{l}\text { CoC: } \mathrm{CM}-\mathrm{f} / 2 \text { medium; } \mathrm{BC}=100 \mathrm{mg}_{\text {dry weight }} \mathrm{L}^{-1} ; \mathrm{HM}- \\
\text { continuous; } \mathrm{EC}=0.8 \mathrm{kWh} \mathrm{m}{ }^{-3} \text {. }\end{array}$ & 17 & {$[20]$} \\
\hline
\end{tabular}

BC - initial biomass concentration, CF - concentration factor, CM - culture medium, CoC - conditions of culturing, EC - energy consumption, HM - harvesting mode, TSS - total suspended solids. 